Review

\title{
The Writers, Readers, and Erasers in Redox Regulation of GAPDH
}

\author{
Maria-Armineh Tossounian, Bruce Zhang and Ivan Gout * \\ Department of Structural and Molecular Biology, University College London, London WC1E 6BT, UK; \\ m.tossounian@ucl.ac.uk (M.-A.T.); bruce.zhang.18@ucl.ac.uk (B.Z.) \\ * Correspondence: i.gout@ucl.ac.uk
}

Received: 23 October 2020; Accepted: 14 December 2020; Published: 16 December 2020

\begin{abstract}
Glyceraldehyde 3-phosphate dehydrogenase (GAPDH) is a key glycolytic enzyme, which is crucial for the breakdown of glucose to provide cellular energy. Over the past decade, GAPDH has been reported to be one of the most prominent cellular targets of post-translational modifications (PTMs), which divert GAPDH toward different non-glycolytic functions. Hence, it is termed a moonlighting protein. During metabolic and oxidative stress, GAPDH is a target of different oxidative PTMs (oxPTM), e.g., sulfenylation, S-thiolation, nitrosylation, and sulfhydration. These modifications alter the enzyme's conformation, subcellular localization, and regulatory interactions with downstream partners, which impact its glycolytic and non-glycolytic functions. In this review, we discuss the redox regulation of GAPDH by different redox writers, which introduce the oxPTM code on GAPDH to instruct a redox response; the GAPDH readers, which decipher the oxPTM code through regulatory interactions and coordinate cellular response via the formation of multi-enzyme signaling complexes; and the redox erasers, which are the reducing systems that regenerate the GAPDH catalytic activity. Human pathologies associated with the oxidation-induced dysregulation of GAPDH are also discussed, featuring the importance of the redox regulation of GAPDH in neurodegeneration and metabolic disorders.
\end{abstract}

Keywords: GAPDH; metabolism; moonlighting protein; redox regulation; oxidative PTMs; $S$-thiolation

\section{Introduction}

Glyceraldehyde-3-phosphate dehydrogenase (GAPDH) is one of the most abundant proteins, well known for its function in cellular metabolism. During glycolysis, GAPDH catalyzes the oxidative phosphorylation of glyceraldehyde-3-phosphate (G3P) to glycerate-1,3-bisphosphate, with the concomitant release of reduced nicotinamide adenine dinucleotide (NADH) [1,2]. The important role of GAPDH in cellular metabolism has led to extensive functional and regulatory studies, which have also uncovered diverse non-glycolytic functions (Figure 1) [3-9]. Many of these functions are controlled by different post-translational modifications (PTMs) on GAPDH, e.g., phosphorylation, acetylation, sulfenylation, nitrosylation, sulfhydration, and S-thiolation, among others [8,10-19]. These PTMs impact the enzymatic activity of GAPDH, its regulatory interactions and its subcellular localization [8,10-19].

The regulation of GAPDH by oxidative PTMs (oxPTMs, e.g., sulfenylation, disulfide bond formation, nitrosylation, sulfhydration, glutathionylation, and other $S$-thiolations) has been the subject of extensive studies since the beginning of this century $[8,17,18,20]$. The catalytic cysteine of GAPDH plays a central role in the redox regulation of GAPDH. Different oxPTMs introduced on the catalytic cysteine inhibit the glycolytic function of GAPDH, causing the disruption of glycolysis. This can lead to rerouting of the cellular carbohydrate flux toward the pentose phosphate shunt, which generates $\mathrm{NADPH}+\mathrm{H}^{+}[21,22]$. The latter plays an important role as the final electron donor to different cellular 
reducing pathways that have a key role in reestablishing and maintaining the cellular reducing environment under stress conditions [22,23]. In this review, we present an overview of the redox regulation of GAPDH by the different redox writers (e.g., hydrogen peroxide). We will also shed light on the consequences of the introduction of oxPTMs on GAPDH and the role of readers and erasers in the redox regulation of its subcellular localization and functional interactions with downstream partners. Finally, we will discuss the different human pathologies (e.g., neurodegeneration and metabolic disorders) associated with the oxidation-induced dysregulation of GAPDH.

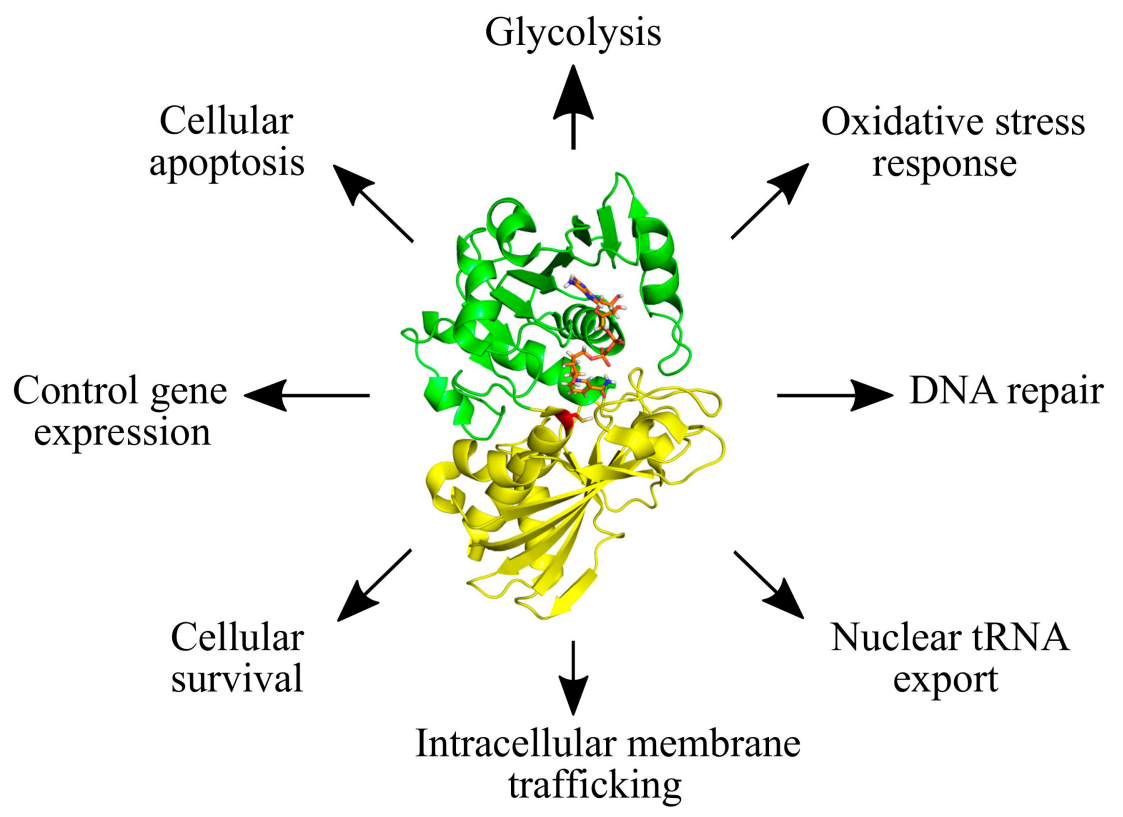

Figure 1. The diversity of cellular functions of GAPDH. Glycolytic and non-glycolytic functions of GAPDH are shown. The structure of GAPDH is featured (PDB ID: 4WNC) with its N-terminal $\mathrm{NAD}^{+}$-binding domain indicated in green, and the $\mathrm{C}$-terminal catalytic domain in yellow. The catalytic cysteine residue is shown in red and the $\mathrm{NAD}^{+}$molecule in orange.

\section{GAPDH Modifications by Redox Writers}

\subsection{Key Features of Redox Writers}

Redox homeostasis is achieved and maintained by the coordinated control of redox reactive species (RRS) production and removal. RRS, such as reactive oxygen (ROS), nitrogen (RNS) and sulfur (RSS) species constitute groups of cellular metabolites, which contribute to the redox balance of the cell. ROS are produced endogenously as by-products of cellular respiration and exhibit a dual role: beneficial or harmful to cells. Under physiological conditions, ROS play an important role in cellular signaling and metabolic pathways. However, prolonged exposure of cells to elevated levels of ROS, caused by environmental variations, metabolic changes or disease [24,25], may lead to the damage of DNA, lipids and proteins [26,27]. ROS can be generated via electron-based redox cycling, and can be in the form of a radical (e.g., hydroxyl radical, superoxide anion) or non-radical (e.g., hydrogen peroxide $\left(\mathrm{H}_{2} \mathrm{O}_{2}\right)$ ). These oxidants, referred to as redox writers in this review, modify target proteins by priming oxPTMs, which can trigger further redox-associated intra- or intermolecular modifications and interactions.

Under oxidizing conditions, such as $\mathrm{H}_{2} \mathrm{O}_{2}$-induced stress, the sulfur-containing cysteine residues are most susceptible to oxidation. At lower levels of $\mathrm{H}_{2} \mathrm{O}_{2}$ (physiological conditions ("oxidative eustress"), 1-10 nM) [28], protein cysteine thiols, which have a high nucleophilic character, are oxidized to a sulfenic acid state (reversible oxPTM) [29]. Higher levels of $\mathrm{H}_{2} \mathrm{O}_{2}$ (supraphysiological conditions ("oxidative distress"), $>100 \mathrm{nM}$ ) [28] can cause further oxidation of the cysteine to a sulfinic acid (mostly 
irreversible oxPTM) or a sulfonic acid (irreversible oxPTM) state (Figure 2) [29]. To prevent cysteine overoxidation and loss of protein function, cysteine residues can form intra- or intermolecular disulfide bonds, as well as mixed disulfides with low molecular weight (LMW) thiols (Figure 2). Formation of a mixed disulfide bond on a protein is termed thiolation, which "edits" the sulfenic acid and creates new redox-induced binding motifs. These motifs are recognized by the "readers", which promote redox signaling and antioxidant response. Reduction of the modified cysteine residues is mediated by specific antioxidant recycling enzymes.

In addition to ROS, during cellular stress, other types of redox writers are also generated, and these include: (a) RNS, such as nitric oxide (NO) and peroxynitrite; and (b) RSS, such as hydrogen sulfide $\left(\mathrm{H}_{2} \mathrm{~S}\right)[30,31]$. Both species are capable of modifying cysteine residues by nitrosylation or sulfhydration, respectively (Figure 2). Overall, once the redox writers (ROS, RNS and RSS) have primed the protein by introducing an "oxPTM code", as part of the "Redox Code" [32], e.g., sulfenylation, nitrosylation or sulfhydration on a target cysteine, the protein's activity, interaction with downstream partners and subcellular localization can be altered.

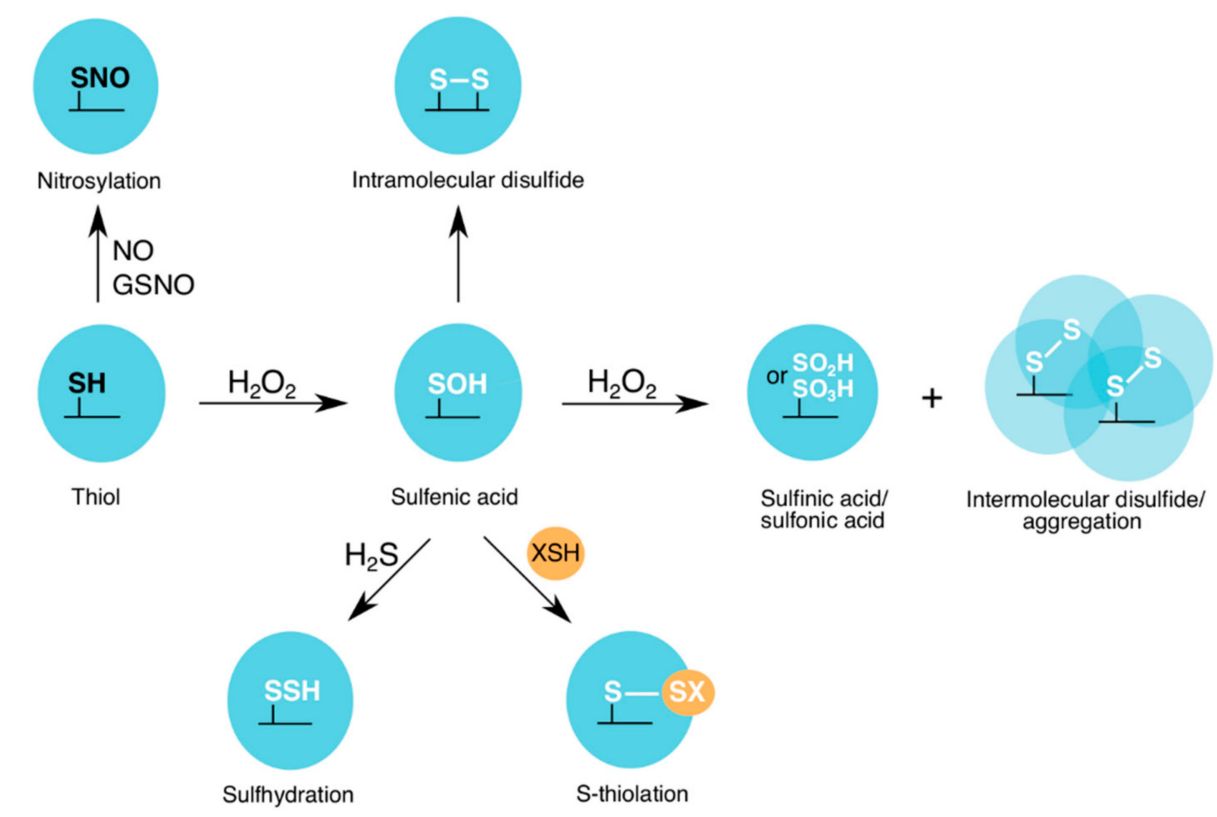

Figure 2. oxPTMs on the catalytic cysteine of GAPDH. At lower levels of $\mathrm{H}_{2} \mathrm{O}_{2}$, a sulfenic acid is formed on the GAPDH catalytic cysteine. However, at higher $\mathrm{H}_{2} \mathrm{O}_{2}$ levels, sulfinic/sulfonic acids and intermolecular disulfides are formed. The latter can lead to GAPDH aggregation. To prevent further cysteine overoxidation, either intramolecular disulfides or mixed disulfides with LMW thiols (e.g., glutathione (GSH), bacillithiol (BSH), mycothiol (MSH) and coenzyme A (CoASH)) are formed. GAPDHs from different organisms have been shown to be nitrosylated or sulfhydrated by nitric oxide (NO) and nitroso-glutathione (GSNO), or hydrogen sulfide $\left(\mathrm{H}_{2} \mathrm{~S}\right)$, respectively.

\subsection{Redox Sensing by GAPDH and Its Regulatory Consequences}

GAPDH is a homo-tetramer, with each monomer composed of two domains: the N-terminal $\mathrm{NAD}^{+}$-binding domain, which displays the characteristic Rossmann fold [33]; and the C-terminal catalytic domain, which carries the conserved catalytic cysteine (Figure 1) [34-37]. During catalysis, the GAPDH catalytic cysteine binds to its substrate (G3P), through a thiohemiacetal intermediate formation. A histidine residue, located in the microenvironment of the active site, facilitates this reaction by lowering the $p K a$ of the catalytic cysteine, leading to its deprotonation, followed by its interaction with G3P $[38,39]$. During oxidative stress, the redox-sensitive catalytic cysteine of GAPDH is modified by different oxPTMs $[8,17,18,40]$, e.g., sulfenylation, disulfide bond formation, nitrosylation, 
sulfhydration, glutathionylation and other forms of $S$-thiolation, which lead to changes in its catalytic activity and glycolytic function [23,41] (Figure 2, Table 1; Table 2).

\subsubsection{Sulfenylation and S-Thiolation of GAPDH}

GAPDH is a highly abundant cellular protein, known to be one of the most prominent targets of $\mathrm{H}_{2} \mathrm{O}_{2}$ during cellular stress $[18,42,43]$. Global proteome analyses of oxidative stress-induced PTMs in different organisms have identified the catalytic cysteine of GAPDH homologs as the most abundant targets of both sulfenylation and S-thiolation [20,40,44-50]. Using genetic (e.g., YAP1C probe) and chemical (e.g., DYn-2 and BTD probes) approaches, combined with mass spectrometric analyses, the Arabidopsis thaliana and Homo sapiens sulfenomes (sulfenylated proteins) were identified [49-53]. Sulfenylation of GAPDH was reported, in addition to other proteins with important metabolic functions. Further in vitro studies showed that $\mathrm{H}_{2} \mathrm{O}_{2}$ oxidizes the GAPDH catalytic cysteine to a sulfenic acid $[23,41,54,55]$, and depending on the GAPDH homolog, this reaction occurs with a second order rate constant of $10-10^{3} \mathrm{M}^{-1} \mathrm{~s}^{-1}[41,55,56]$. Subsequently, the sulfenic acid can form intra- or intermolecular disulfide bonds, as well as mixed-disulfides with LMW thiols (Figure 2, Tables 1 and 2). An in vitro study performed by Nakajima et al. (2007) showed that the rabbit muscle GAPDH undergoes conformational changes in the presence of oxidizing agents (e.g., nitric oxide) [57]. These conformational changes facilitate the formation of an intermolecular disulfide bond between two catalytic cysteine residues of GAPDH [57]. The latter induces further conformational changes, which expose non-catalytic cysteine residues. The exposed cysteines then form additional intermolecular disulfide bonds, leading to GAPDH oligomerization and aggregation (Figure 2) [57]. GAPDH aggregation is observed in diseases such as Alzheimer's disease (Section 5).

Table 1. Examples of catalytic cysteine oxidation states of different GAPDH homologs.

\begin{tabular}{cccccc}
\hline \multicolumn{5}{c}{ Cysteine Oxidation to Sulfenic, Sulfinic and Sulfonic Acids or Disulfide Bond Formation } \\
\hline Target Protein & Oxidant & Cys Residue & oxPTM & $\begin{array}{c}\text { Influence on } \\
\text { Enzymatic Activity }\end{array}$ & Ref. \\
\hline $\begin{array}{l}\text { H. sapien } \\
\text { GAPDH }\end{array}$ & $\mathrm{H}_{2} \mathrm{O}_{2}$ & Cys152 & $\begin{array}{c}\text { Sulfenic and } \\
\text { sulfonic acids }\end{array}$ & Inhibition & [23] \\
\hline $\begin{array}{c}\text { Rabbit muscle } \\
\text { GAPDH }\end{array}$ & $\mathrm{H}_{2} \mathrm{O}_{2}$ & Cys150-Cys154 & $\begin{array}{c}\text { Intramolecular } \\
\text { disulfide bonds }\end{array}$ & Inhibition & {$[58]$} \\
\hline $\begin{array}{c}\text { A. thaliana } \\
\text { GAPC1 }\end{array}$ & $\mathrm{H}_{2} \mathrm{O}_{2}$ & Cys155 & $\begin{array}{c}\text { Sulfenic, sulfinic } \\
\text { and sulfonic acids }\end{array}$ & Inhibition & [59] \\
\hline $\begin{array}{c}\text { C.diphtheriae } \\
\text { GAPDH }\end{array}$ & $\mathrm{H}_{2} \mathrm{O}_{2}, \mathrm{NaOCl}$ & $\begin{array}{c}\text { Cys153, } \\
\text { Cys153-Cys157 }\end{array}$ & $\begin{array}{c}\text { Sulfonic acid, and } \\
\text { intramolecular } \\
\text { disulfide bond }\end{array}$ & Inhibition & [47] \\
\hline
\end{tabular}

In addition to intra/intermolecular disulfide bond formation, GAPDH can also form mixed disulfide bonds with LMW thiols, which serve as cellular redox buffers and contribute to the protection of proteins from $\mathrm{H}_{2} \mathrm{O}_{2}$ and other oxidants [60,61]. GAPDH has been reported to form mixed-disulfides with various LMW thiols, including glutathione (GSH—eukaryotes and Gram-negative bacteria), bacillithiol (BSH-Gram-positive Firmicutes), mycothiol (MSH-Actinobacteria) and coenzyme A (CoA—all organisms) (Figure 2, Table 2) [20,40,46,47,58,59,62].

Glutathionylation of GAPDH-Glutathione is a tripeptide composed of $\gamma$-glutamyl-cysteinyl -glycine, which is involved in numerous detoxification reactions and functions as a major cellular antioxidant $[60,63,64]$. GAPDH glutathionylation protects the catalytic cysteine from overoxidation (Figure 2), and subsequently, inactivates the glycolytic function of GAPDH (Table 2) [65-68]. GAPDH glutathionylation has been reported in different organisms including yeast, unicellular protozoan (Plasmodium falciparum), rabbit muscle cells and plants (A. thaliana), among others $[48,58,59,69,70]$. In vitro studies demonstrated that in the presence of $\mathrm{H}_{2} \mathrm{O}_{2}$, rabbit muscle GAPDH acquired two 
oxPTMs: glutathionylation on its catalytic cysteine (Cys150), and the formation of an intramolecular disulfide bond between Cys150 and Cys154 (non-catalytic cysteine) (Figure 2) [58]. Both redox modifications led to the reversible inactivation of GAPDH. Upon glutathionylation of GAPDH, Barinova et al. (2017) reported structural changes associated with the oxidation-induced dissociation of $\mathrm{NAD}^{+}$from the active site and the decrease in GAPDH thermal stability [58]. This structural change may influence the inactivation of the enzyme and its interaction with downstream interacting partners.

In addition to $\mathrm{H}_{2} \mathrm{O}_{2}$-induced GAPDH glutathionylation, the catalytic cysteine of GAPDH can be glutathionylated by nitroso-glutathione (GSNO) under cellular nitrosative stress [71,72]. GSNO is considered to be the main nitric oxide (NO) reservoir within cells, and it can induce both trans-nitrosylation and glutathionylation of GAPDH and other proteins [73]. The cellular level of GSNO is controlled by prokaryotic and eukaryotic GSNO reductases [74].

Bacillithiolation and Mycothiolation of GAPDH-Most Gram-positive bacteria do not produce GSH and instead use other types of LMW thiols. Actinobacteria, e.g., Corynebacterium diphtheriae and Mycobacterium tuberculosis, use mycothiol (MSH) as their major LMW thiol $[75,76]$. Structurally different from GSH, MSH is composed of a cysteine residue in which the amino group is acetylated, and the carboxy group linked to glucosamine, which in turn is linked to myo-inositol $[77,78]$. Using shotgun liquid chromatography tandem mass spectrometry (LC-MS/MS) analysis, 26 mycothiolated proteins were identified from the proteome of $C$. diphtheriae subjected to hypochlorite $(\mathrm{NaOCl})$ stress [47]. GAPDH was identified as the most abundant mycothiolated protein $(0.75 \%$ of the total Cys proteome). In vitro studies using recombinant $C$. diphtheriae GAPDH demonstrated that its catalytic cysteine (Cys153) is protected from overoxidation by both mycothiolation and intramolecular disulfide bond formation in the presence of $\mathrm{H}_{2} \mathrm{O}_{2}$ and $\mathrm{NaOCl}$. Mycothiolation of the active site cysteine was reported to inhibit its catalytic activity [47].

Other Gram-positive bacteria, e.g., Staphylococcus aureus and Bacillus subtilis, produce and use bacillithiol (BSH) as LMW thiol [20,79-81]. BSH structure is composed of a glycoside formed between L-cysteinyl-D-glucosamine and malic acid [79]. GAPDH was identified as the most abundant bacillithiolated protein in the proteomic study of $S$. aureus $(\mathrm{Sa}$ ) subjected to $\mathrm{NaOCl}$ stress [46]. In the presence of $\mathrm{H}_{2} \mathrm{O}_{2}$ or NaOCl, Sa-GAPDH is bacillithiolated (in vitro) on Cys151, which reversibly inhibits its catalytic activity [46]. Molecular docking studies of BSH into the active site of GAPDH suggested that disulfide bond formation between BSH and Cys151 occurs without major conformational changes, making GAPDH the preferred bacillithiolation site in S. aureus under $\mathrm{NaOCl}$ stress [46].

CoAlation of GAPDH - Coenzyme A is an essential cofactor in all living cells. It is synthesized by an evolutionarily conserved pathway, which requires ATP, pantothenate (vitamin B5) and a cysteine residue [82]. CoA functions as a key metabolic cofactor in numerous catabolic and anabolic reactions. Recently, a novel antioxidant function of CoA was uncovered in eukaryotic and prokaryotic cells in response to oxidative and metabolic stress, and termed protein CoAlation [20,44]. Using CoA-specific monoclonal antibodies and tandem mass spectrometry, more than 1000 CoAlated proteins were identified from mammalian and prokaryotic cells subjected to oxidative or metabolic stress $[20,44,83]$. Under various stress conditions, GAPDH CoAlation is observed in numerous proteomic studies e.g., in mammalian cells and tissues, and in bacteria (Gram-positive S. aureus and B. subtilis, and Gram-negative Citobacter sp. 5-77) [20,44,62]. Tsuchiya et al. (2018) reported the reversible inactivation of $S a-G A P D H$ upon CoAlation [20]. Molecular dynamics studies proposed a possible mode of CoA binding to oxidized $\mathrm{Sa}$-GAPDH that includes an initial binding of the CoA ADP moiety to the vacant $\mathrm{NAD}^{+}$-binding site (Rossmann fold), which would allow the CoA pantetheine tail to reach the catalytic Cys151 residue of GAPDH and form a mixed disulfide bond [20]. Citobacter sp. 5-77 GAPDH was also shown to be reversibly inactivated upon CoAlation of its catalytic Cys149 [62].

CoA has recently been reported to form a nitroso-coenzyme A (SNO-CoA) heterodimer in the presence of nitric oxide (NO) [84]. SNO-CoA and GSNO are involved in protein trans-nitrosylation [72,84]. In addition to trans-nitrosylation, GSNO can also trans-glutathionylate proteins, while the role of SNO-CoA in mediating protein CoAlation remains to be investigated. The study may shed light on the 
regulation of proteins (e.g., GAPDH) by SNO-CoA-mediated CoAlation during cellular nitrosative stress. SNO-CoA reductases, which reduce SNO-CoA, have been reported and proposed to play an important role in the mechanisms involving metabolic regulation by NO [84].

\subsubsection{Nitrosylation and Sulfhydration of GAPDH}

In addition to ROS, reactive nitrogen (RNS) and sulfur (RSS) species are also produced during cellular stress, and contribute to different signaling pathways by introducing oxPTMs on proteins. Nitric oxide (NO) is a highly reactive molecule, which participates in diverse cellular signaling pathways. It causes the formation of nitrosothiol on proteins, which is termed nitrosylation (Figure 2) [85]. Protein nitrosylation can occur chemically by $\mathrm{NO}$ and peroxynitrite, or through trans-nitrosylation by nitrosothiols (e.g., GSNO or SNO-CoA) or other nitrosylated proteins $[85,86]$. The catalytic cysteine of GAPDH is a target of nitrosylation by NO and GSNO (Figure 2, Table 2), which leads to the reversible inhibition of its catalytic activity [71,73], translocation from the cytoplasm to the nucleus or mitochondria, and its contribution to different cellular processes e.g., apoptosis [8].

Similar to $\mathrm{NO}, \mathrm{H}_{2} \mathrm{~S}$ can also target protein cysteine thiols (sulfhydration) to form persulfide bonds (-SSH) (Figure 2). Protein sulfhydration is reported to be a more abundant PTM compared to nitrosylation within liver lysates [17]. GAPDH has been identified as a target of sulfhydration $[17,87,88]$. Mustafa et al. (2009) reported the sulfhydration of the catalytic cysteine of GAPDH from mouse liver lysate, which was treated with sodium hydrogen sulfide (NaHS- $\mathrm{H}_{2} \mathrm{~S}$ donor) [17]. GAPDH sulfhydration on the catalytic cysteine was also reported in HEK293 cells treated with NaHS, which led to an increase in its activity (Table 2) [17]. In a separate study, Gao et al. (2015) observed an increase in GAPDH activity in response to elevated $\mathrm{H}_{2} \mathrm{~S}$ production in the pancreatic cell line, MIN6, during ER stress [89]. In vitro studies revealed that inhibition of the activity of GAPDH by $\mathrm{H}_{2} \mathrm{O}_{2}$ and GSSG (glutathione disulfide) was reversed by $\mathrm{H}_{2} \mathrm{~S}$ treatment [89]. Overall, the study by Gao et al. (2015) proposed that during ER stress, the control of $\mathrm{H}_{2} \mathrm{~S}$ synthesis might regulate the activity of proteins involved in metabolic pathways (e.g., GAPDH) [89]. An in vitro study performed by Jarosz et al. (2015) reported a decrease in GAPDH activity in the presence of persulfides [88]. Furthermore, Jarosz et al. (2015) demonstrated that the activity of glutathionylated GAPDH is lower than that of the reduced enzyme, and can be partially restored upon treatment with NaHS [88]. Overall, in these studies, sulfhydration has been reported to impact the catalytic activity of GAPDH.

\subsubsection{Methionine Oxidation, Cysteine Disulfide Formation and GAPDH Aggregation}

Human diseases (e.g., Alzheimer's disease-Section 5) are associated with the aggregation of GAPDH due to the formation of intermolecular disulfides [57,90-92]. An in vitro study performed by Nakajima et al. (2007) showed that the rabbit muscle GAPDH undergoes conformational changes, and forms intermolecular disulfide bonds that lead to the aggregation of GAPDH [57]. In a later study, which focuses on the mechanism of GAPDH aggregation, Samson et al. (2014) reported that the oxidation of a highly conserved Met 46 of GAPDH to methionine sulfoxide, could cause structural changes, which facilitate cysteine intermolecular disulfide formation and GAPDH aggregation [93]. In this study, the authors propose that oxidation of Met46 could initiate GAPDH structural changes, which lead to aggregation [93]. 
Table 2. Examples of S-thiolations (glutathionylation, mycothiolation, bacillithiolation and CoAlation), nitrosylation and sulfhydration on the catalytic cysteine of different GAPDH homologs. The cysteine residues shown within the table are the catalytic cysteines of the GAPDH homologs.

\begin{tabular}{|c|c|c|c|c|c|c|}
\hline \multicolumn{7}{|c|}{ Regulatory S-Thiolations on GAPDH } \\
\hline Target Protein & $\begin{array}{l}\text { Oxidant or } \\
\text { Molecule }\end{array}$ & Residue & oxPTM & $\begin{array}{c}\text { Influence on } \\
\text { Enzymatic } \\
\text { Activity }\end{array}$ & Recycling & Ref. \\
\hline $\begin{array}{l}\text { P. falciparum } \\
\text { GAPDH }\end{array}$ & GSSG & Cys153 & $\begin{array}{l}\text { Glutathion } \\
\text { ylation }\end{array}$ & $\begin{array}{c}\text { Reversible } \\
\text { inhibition }\end{array}$ & $\begin{array}{l}\text { Grx1, Trx } \\
\text { and plasmo- } \\
\text { redoxin }\end{array}$ & [70] \\
\hline $\begin{array}{l}\text { Rabbit muscle } \\
\text { GAPDH }\end{array}$ & $\mathrm{H}_{2} \mathrm{O}_{2}(+\mathrm{GSH})$ & Cys150 & Glutathionylation & $\begin{array}{c}\text { Reversible } \\
\text { inhibition }\end{array}$ & $\begin{array}{c}\text { Excess GSH, } \\
\text { and } \operatorname{Trx}\end{array}$ & [58] \\
\hline $\begin{array}{l}\text { A. thaliana } \\
\text { GAPC1 }\end{array}$ & $\begin{array}{c}\text { GSSG, and } \\
\mathrm{H}_{2} \mathrm{O}_{2}(>+\mathrm{GSH})\end{array}$ & Cys155* & Glutathionylation & $\begin{array}{c}\text { Reversible } \\
\text { inhibition }\end{array}$ & $\begin{array}{c}\text { GrxC1, and } \\
\text { Trx }\end{array}$ & [59] \\
\hline $\begin{array}{l}\text { A. thaliana } \\
\text { A4-GAPDH }\end{array}$ & $\begin{array}{c}\text { GSSG, and } \\
\mathrm{H}_{2} \mathrm{O}_{2}(+\mathrm{GSH})\end{array}$ & Cys149 & Glutathionylation & $\begin{array}{c}\text { Reversible } \\
\text { inhibition }\end{array}$ & $\begin{array}{l}\text { Grx1, and } \\
\text { Grx3 }\end{array}$ & $\begin{array}{l}{[94,} \\
95]\end{array}$ \\
\hline $\begin{array}{c}\text { H. sapiens } \\
\text { GAPDH }\end{array}$ & $\mathrm{H}_{2} \mathrm{O}_{2}(+\mathrm{GSH})$ & Cys152 & Glutathionylation & $\begin{array}{l}\text { Reversible } \\
\text { inhibition }\end{array}$ & DTT & [23] \\
\hline $\begin{array}{l}\text { C. diphtheriae } \\
\text { GAPDH }\end{array}$ & $\begin{array}{c}\mathrm{H}_{2} \mathrm{O}_{2}(+\mathrm{MSH}) \\
\text { and } \mathrm{NaOCl} \\
(+\mathrm{MSH})\end{array}$ & Cys153 & Mycothiolation & $\begin{array}{c}\text { Reversible } \\
\text { inhibition }\end{array}$ & $\begin{array}{l}\text { Mrx1, and } \\
\text { Trx }\end{array}$ & [47] \\
\hline $\begin{array}{l}\text { S. aureus } \\
\text { GAPDH }\end{array}$ & $\begin{array}{c}\mathrm{H}_{2} \mathrm{O}_{2}(+\mathrm{BSH}) \\
\text { and } \mathrm{NaOCl} \\
(+\mathrm{BSH})\end{array}$ & Cys151 & Bacillithiolation & $\begin{array}{c}\text { Reversible } \\
\text { inhibition }\end{array}$ & Brx & [46] \\
\hline $\begin{array}{l}\text { S. aureus } \\
\text { GAPDH1 }\end{array}$ & CoASSCoA & Cys151 & CoAlation & $\begin{array}{c}\text { Reversible } \\
\text { inhibition }\end{array}$ & DTT & [20] \\
\hline $\begin{array}{l}\text { Citobacter sp. } \\
\text { 5-77 GAPDH }\end{array}$ & $\begin{array}{c}\mathrm{CoASSCoA}, \\
\mathrm{NaOCl}(+\mathrm{CoA}), \\
\text { and } \mathrm{H}_{2} \mathrm{O}_{2} \\
(+\mathrm{CoA})\end{array}$ & Cys149 & CoAlation & $\begin{array}{c}\text { Reversible } \\
\text { inhibition }\end{array}$ & $\begin{array}{c}\text { Excess DTT, } \\
\text { GSH, and } \\
\text { CoA }\end{array}$ & [62] \\
\hline
\end{tabular}

Nitrosylation and Sulfhydration of GAPDH

\begin{tabular}{|c|c|c|c|c|c|c|}
\hline Target Protein & $\begin{array}{l}\text { Oxidant or } \\
\text { Molecule }\end{array}$ & Residue & oxPTM & $\begin{array}{c}\text { Influence on } \\
\text { Enzymatic } \\
\text { Activity }\end{array}$ & Recycling & Ref. \\
\hline $\begin{array}{l}\text { A. thaliana } \\
\text { GAPC1 }\end{array}$ & GSNO & Cys155* & Nitrosylation & $\begin{array}{l}\text { Reversible } \\
\text { inhibition }\end{array}$ & GSH & [72] \\
\hline $\begin{array}{c}\text { GAPDH } \\
\text { (SH-Sy5Y cell } \\
\text { extract) }\end{array}$ & SNO-Trx1 & Cys247 & Nitrosylation & $\begin{array}{l}\text { Reversible } \\
\text { inhibition }\end{array}$ & $\begin{array}{l}\text { Reduced } \\
\text { Trx1 }\end{array}$ & $\begin{array}{l}{[96,} \\
97]\end{array}$ \\
\hline $\begin{array}{c}\text { GAPDH } \\
\text { (HEK293 } \\
\text { extract) }\end{array}$ & $\mathrm{H}_{2} \mathrm{~S}$ & Cys152 & Sulfhydration & $\begin{array}{l}\text { Activity } \\
\text { increase }\end{array}$ & DTT & [17] \\
\hline
\end{tabular}

\section{Decoding of the GAPDH Redox Communication}

Diverse proteins have been identified, which recognize and interact with redox-modified GAPDH, regulating its glycolytic and non-glycolytic (moonlighting) functions. In this section, we describe these GAPDH readers, particularly focusing on those proteins, which decode and transduce the redox information, or amplify it via the attachment of LMW thiols (e.g., for the case of sulfenylated GAPDH). 


\subsection{Readers of Sulfenylated and S-Thiolated GAPDH}

The catalytic cysteine of GAPDH plays a crucial role in defining its activity, interaction with partners, and its role in the regulation of cellular processes. A study performed in Schizosaccharomyces pombe showed that under $\mathrm{H}_{2} \mathrm{O}_{2}$-induced stress, redox-modified GAPDH participates in phospho-relay signaling [98]. S. pombe phosphorelay signaling is activated by external stimuli (e.g., $\mathrm{H}_{2} \mathrm{O}_{2}$ ) and is composed of a two-component system: (a) the multi-step phosphorelay (sensor kinase, phosphotransferase and response regulator, Mcs4), which transmits $\mathrm{H}_{2} \mathrm{O}_{2}$ stress signal to (b) the mitogen-activated protein kinase (MAPK) cascade $[99,100]$. Mcs4 (response regulator) activates MAPK cascade. In response to $\mathrm{H}_{2} \mathrm{O}_{2}$-induced stress, the catalytic cysteine (Cys152) of S. pombe GAPDH (Tdh1) is transiently oxidized, and in turn, enhances the association of Tdh1 with Mcs4 [98]. Therefore, in S. pombe, oxidation of GAPDH may provide additional input signal, and promote peroxide stress signaling through the multistep phosphrelay system [98]. In addition, the $t d h 1$ null mutant cells have a reduced $\mathrm{H}_{2} \mathrm{O}_{2}$-stress response through phosphorelay signaling, compared to wild-type cells [98].

In another study, the $\mathrm{H}_{2} \mathrm{O}_{2}$-induced modification on the catalytic cysteine of mammalian GAPDH is reported to participate in the $\mathrm{H}_{2} \mathrm{O}_{2}$-dependent activation of mammalian phospholipase D2 (PLD2) in PC12 cells, which mediates an anti-apoptotic effect during oxidative stress [101,102]. PLD2 catalyzes the hydrolysis of the phosphodiester bond of phosphatidylcholine, which generates phosphatidic acid, a lipid second messenger [103]. The study shows that the $\mathrm{H}_{2} \mathrm{O}_{2}$-modified catalytic cysteine of GAPDH acts as a positive regulator of PLD2 [101].

In both examples mentioned above, oxidation of GAPDH enhances its recognition and binding to different types of GAPDH readers. Alternatively, GAPDH readers may also recognize the $S$-thiolated form of GAPDH. For example, CoAlation of GAPDH introduces a bulky molecule (pantetheine tail and ADP moiety) within the GAPDH active site [20]. The CoA ADP moiety could be recognized by Rossmann fold-containing proteins (readers), which can facilitate the interaction between GAPDH and the reader protein. The interaction between these readers and GAPDH could potentially lead to the regulation of different cellular processes. Similarly, the S-mycothiolation or S-bacillithiolation of GAPDH may possibly enhance binding of proteins that recognize these bulky molecules, which are covalently bound to the GAPDH catalytic cysteine residue.

\subsection{Readers of Nitrosylated GAPDH}

\subsubsection{Nuclear Transportation and Cellular Apoptosis}

Nitrosylation of mammalian GAPDH has been associated with triggering an apoptotic cascade, which is initiated in the cytoplasm. When cells are initially exposed to a stressor, and the level of nitric oxide (NO) within cells becomes slightly higher than physiological concentrations, GOSPEL (GAPDH's Competitor of Siah Protein Enhances Life) becomes nitrosylated on Cys47, binds to GAPDH, and competes with Siah1, an E3 ubiquitin ligase, to retain GAPDH in the cytoplasm [104]. The binding of GOSPEL to GAPDH maintains cellular homeostasis under nitrosative stress, and prevents the triggering of a cellular apoptotic cascade [104]. However, an increase in the level of nitrosative stress beyond a certain threshold leads to the nitrosylation of the catalytic Cys150 of rat GAPDH (forming SNO-GAPDH) [8]. SNO-GAPDH is recognized by Siah1, and their interaction is induced by cell stressors which augment nitric oxide production. Siah1 marks proteins for proteasomal degradation by ubiquitinating the target proteins. It contains a nuclear localization signal, which mediates the translocation of the SNO-GAPDH-Siah1 complex to the nucleus [8]. The nuclear complex interacts with various target proteins and regulates their function by e.g., ubiquitination, acetylation or trans-nitrosylation, which lead to apoptosis.

Once in the nucleus, the stabilized Siah1 causes ubiquitination and subsequent degradation of the nuclear co-repressor (N-Cor), which contributes to cellular apoptosis. On the other hand, nuclear SNO-GAPDH directly interacts with the acetyltransferase p300/CBP (CREB-binding protein) [105]. Their binding initiates the auto-acetylation and subsequent activation of p300/CBP, which acetylates 
downstream targets (including tumor suppressor p53) that contribute to cellular apoptosis [105]. Once activated, p53 induces apoptosis by trans-activating numerous downstream pro-apoptotic genes, e.g., mainly the expression of p53-up-regulated modulator of apoptosis (PUMA) $[105,106]$. Nuclear SNO-GAPDH can also trans-nitrosylate and alter the function of several nuclear proteins e.g., deacetylase sirtuin-1 (SIRT1), histone deacetylase-2 (HDAC2) and DNA-activated protein kinase (DNA-PK) [107].

An alternative mechanism for the binding of oxidized GAPDH to Siah1 has been reported [108]. It involves the apoptosis signal-regulating kinase 1 (ASK1), which is activated in response to different cellular stresses $[109,110]$. Tristan et al. (2015) reported that ASK1 could enhance the interaction between GAPDH and Siah1 by phosphorylating Siah1. This in turn leads to the activation of GAPDH-Siah1 nuclear signaling cascade, followed by the activation of acetyltransferase p300, and the induction of cellular apoptosis [108].

In addition to the induction of an apoptotic cascade, nuclear GAPDH also participates in DNA repair, DNA replication and telomere maintenance $[6,7]$.

\subsubsection{GAPDH Translocation to the Mitochondria}

Upon exposure to stress, the level of mitochondrial GAPDH has been reported to increase [111,112]. This may indicate the functional requirement of GAPDH within the mitochondria during cellular stress. Kohr et al. (2014) show that SNO-GAPDH is able to translocate to the matrix of mitochondria isolated from ischemically preconditioned mouse heart [112]. Mitochondrial ischemic preconditioning has been reported to increase the level of nitrosylated mitochondrial proteins [113]. Several mitochondrial proteins, e.g., voltage-dependent anion channel (VDAC1—outer mitochondrial membrane), Hsp60 and acetyl-CoA acetyltransferase (ACAT1), were shown to interact with and to be transnitrosylated by SNO-GAPDH [112]. Therefore, future studies might shed light on the role of SNO-GAPDH in regulating mitochondrial function by trans-nitrosylating specific mitochondrial proteins and regulating their function.

\subsection{Readers of Sulfhydrated GAPDH}

Mir et al. (2014) reported that interleukin-1 $\beta$ causes the degradation of postsynaptic density 95 (PSD95) in a $\mathrm{H}_{2} \mathrm{~S}$-dependent manner [114]. PSD95 is a scaffolding protein, which plays an important role in synapse maturation, stability, and plasticity [115]. In the presence of IL-1 $\beta$, the expression of cystathionine beta-synthase (CBS) increases, which leads to the production of $\mathrm{H}_{2} \mathrm{~S}$. Upon exposure to $\mathrm{H}_{2} \mathrm{~S}$, GAPDH is reported to become sulfhydrated and binds to Siah1 [114]. In complex with sulfhydrated GAPDH, Siah1 interacts with and ubiquitinates PSD95, which results in PSD95 degradation and synapse loss within the brain [114].

\section{Erasers of Redox-Associated Modifications}

"Redox erasers" remove redox-associated modifications and restore the reduced form of modified proteins. In turn, they network with other antioxidant enzymes/molecules to restore their own activity by using $\mathrm{NADPH}+\mathrm{H}^{+}$as the final electron donor. In this section, we will focus on the redox regulation of GAPDH by the thioredoxin pathway and the LMW thiol pathways (Figure 3). 
A

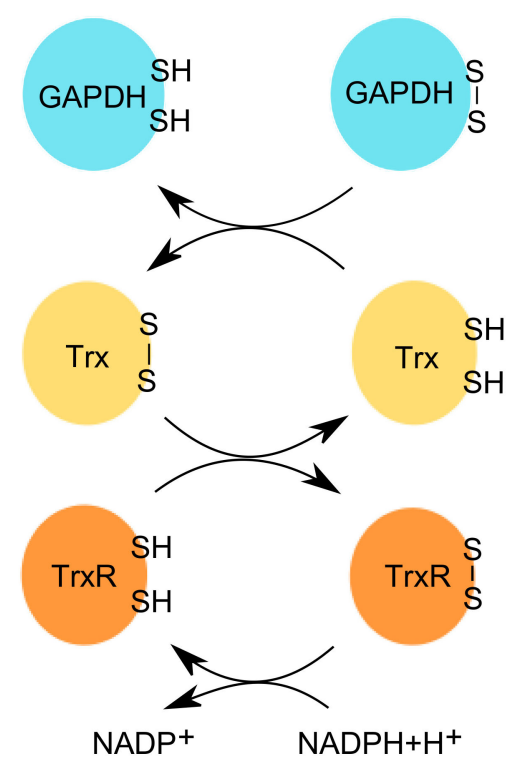

B

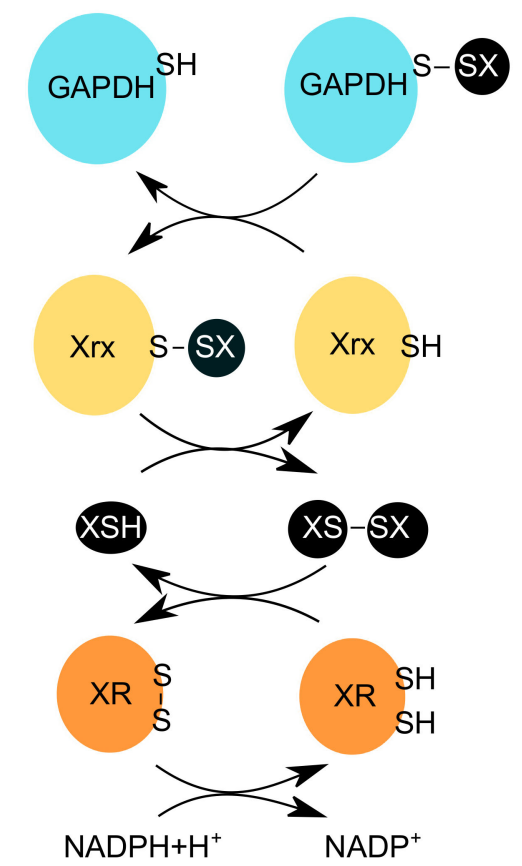

Figure 3. Redox erasers restore the reduced and active form of GAPDH. OxPTMs introduced on GAPDH by the redox writers (e.g., $\mathrm{H}_{2} \mathrm{O}_{2}$ ) and editors (e.g., $\mathrm{XSH}$, where $\mathrm{X}$ can be glutathione, or other LMW thiols, e.g., mycothiol, bacillithiol or coenzyme A), are removed by redox erasers e.g., (A) thioredoxin (Trx), or (B) glutaredoxin (Grx), respectively. (A) Trx reduces the disulfide bond on GAPDH. This leads to the release of the reduced form of GAPDH, and the oxidized form of Trx. The latter is then reduced by TrxR, which uses NADPH $+\mathrm{H}^{+}$to restore its reduced form. (B) Redoxins (Xrx) e.g., glutaredoxins (Grx), reduce the glutathionylated form of GAPDH. This leads to the release of the reduced form of GAPDH, and the subsequent glutathionylation of Grx. Another molecule of e.g., GSH, can then reduce Grx, and in turn, form glutathione disulfide (GSSG). The latter is then reduced by glutathione reductase (GR), which uses $\mathrm{NADPH}+\mathrm{H}^{+}$to restore its reduced form.

\subsection{Key Features of Cellular Redox Erasers}

Redox-sensitive cysteines participate in diverse cellular signaling and metabolic pathways. The activity and coordination of these cysteines depend on molecular thiol switches such as thioredoxin (Trx) and glutaredoxin (Grx) (Figure 3). The thioredoxin pathway takes part in the cellular antioxidant response by reducing disulfide bonds formed on target proteins. This pathway catalyzes the electron transfer from $\mathrm{NADPH}+\mathrm{H}^{+}$, through the flavoenzyme thioredoxin reductase (TrxR) to Trx. The latter can control numerous signaling pathways by interacting with and transferring electrons to different proteins, which form disulfide bonds when oxidized (Figure 3) [116-119]. Another reducing enzyme is glutaredoxin (Grx), which can deglutathionylate proteins via the monothiol mechanism.

$S$-glutathionylation is reversed by Grx, which can reduce the mixed disulfide bond and subsequently, become itself glutathionylated. The second mixed disulfide between GSH and Grx is then attacked by another GSH molecule resulting in the release of the reduced form of Grx and a glutathione disulfide molecule (GSSG). The GSSG is reduced by glutathione reductase (GR), which uses $\mathrm{NADPH}+\mathrm{H}^{+}$as its final electron donor (Figure 3) $[120,121]$. 


\subsection{Erasers of GAPDH Redox Modifications}

\subsubsection{Erasers of Intra- and Intermolecular Disulfide Bonds}

The redox-induced formation of intra- and intermolecular disulfide bonds has been reported for GAPDH (Table 1) [93,122-124]. Different reducing pathways participate in recycling the oxidized GAPDH, and in recovering its catalytic activity (Figure 3, Table 1). Landino et al. (2014) showed that the $\mathrm{H}_{2} \mathrm{O}_{2}$-induced oxidation of GAPDH resulted in the formation of disulfide bonds, which were reduced by the Trx pathway [123]. Interestingly, within the same study, they showed a possible thiol-disulfide exchange between tubulin and GAPDH, making tubulin a potential redox eraser of oxidized GAPDH [123]. Future studies on understanding the detailed thiol-disulfide exchange mechanism between tubulin and oxidized GAPDH may shed light on how tubulin could potentially function as a redox eraser. Important to note is that tubulin is an abundant protein in neuronal cells, which interacts with different microtubule-associated proteins (MAP) such as Tau and MAP2 [125]. These proteins have been reported to be redox-sensitive and can form disulfide bonds that reduce their microtubule binding ability. Trx and Grx are reported to reduce these disulfides and restore their function [126-128].

\subsubsection{Erasers of GAPDH S-Thiolation}

Redox erasers, such as thioredoxins, glutaredoxins, mycoredoxins, bacilliredoxins and CoAredoxins use thiol-disulfide exchange mechanisms to regulate proteins with diverse cellular functions (Figure 3 and Table 2). The mechanisms of GAPDH deglutathionylation have been studied in numerous organisms, such as yeast, unicellular protozoans (P. falciparum), plants (A. thaliana) and animals $[48,59,69,70,94,129]$. The catalytic activity of the glutathionylated cytosolic $A$. thaliana GAPDH (GapC1 isoform) recovers upon treatment with cytosolic Grx [59]. The latter deglutathionylates GAPDH using the GSH-dependent monothiol mechanism, and restores its catalytic activity. Interestingly, although Trx enzymes have been reported to reduce sulfenic acids and disulfide bonds, recent studies have revealed that they can also participate in the deglutathionylation of GapC1, but less efficiently compared to Grx [59]. The activity of glutathionylated P. falciparum GAPDH is also restored upon treatment with both Grx1 and Trx1, in addition to the P. falciparum-specific plasmoredoxin [70]. The glutathionylated $A$. thaliana chloroplastic GAPDH (A4-GAPDH isoform) was deglutathionylated by Grx1 (cytosolic isoform) and Grx3 (chloroplastic isoform) [94], while glutathionylated yeast GAPDH (Tdh3) was deglutathionylated by Trx1, Trx2 [69], and the yeast mitochondrial matrix Grx5 [130]. Interestingly, the glutathionylated rabbit muscle GAPDH was reported to be deglutathionylated non-enzymatically in the presence of GSH or enzymatically by Trx [58]. The latter only partially reactivated GAPDH [58]. Overall, the mechanisms of protein deglutathionylation depend on the organism, subcellular localization of GAPDH, and the availability and specificity of "redox eraser" isoforms.

Demycothiolation of GAPDH was found to involve mycoredoxin-1 (Mrx1) and thioredoxin. The latter was considered to be less efficient in demycothiolating GAPDH compared to Mrx1 [47]. Bacillithiol-modified S. aureus GAPDH is shown to be debacillithiolated by bacilliredoxin, which uses $\mathrm{BSH}$, bacillithiol disulfide reductase and $\mathrm{NADPH}+\mathrm{H}^{+}$to restore its activity $[46,131]$. In contrast, the mechanism of protein deCoAlation is not well understood. Analysis of mammalian and bacterial cells exposed to different oxidative and metabolic stresses revealed extensive protein CoAlation, which was rapidly reversed after the removal of oxidizing agents $[20,44]$. This suggests the presence of a CoAredoxin activity, which remains to be further explored. A study performed by Tsuji et al. (2019) showed that Citrobacter sp. S-77 GAPDH can be in vitro deCoAlated non-enzymatically by excess of GSH, and less efficiently by excess of CoA [62]. 


\subsubsection{Erasers of GAPDH Nitrosylation and Sulfhydration}

A recent study showed that human GAPDH could also be trans-nitrosylated by the nitrosylated form of thioredoxin-1 (SNO-Trx1). Interestingly, the reduced form of Trx1 was proposed to denitrosylate SNO-GAPDH, which restored its catalytic activity $[96,97,132]$. Therefore, Trx1 may play an important role by regulating the apoptotic function of GAPDH via nitrosylation/denitrosylation mechanisms. A study performed on the A thaliana cytosolic GAPDH (GapC1) showed that SNO-GAPDH is denitrosylated non-enzymatically in the presence of excess GSH [72]. This GSH-dependent denitrosylation of GAPDH fully recovered its catalytic activity, without glutathionylating GAPDH. Further studies demonstrated that the GapC1 denitrosylation was directly linked to the cellular ratio between glutathione and nitrosoglutathione ([GSH]/[GSNO]) [72].

Knowledge of the desulfhydration mechanism of GAPDH is emerging. Ju et al. (2016) showed that thioredoxin can desulfhydrate proteins. Cells overexpressing Trx 1 showed a decrease in the level of sulfhydrated proteins, which included GAPDH. Mutation of the Trx catalytic cysteine (Cys32) abolished its GAPDH desulfhydration function [133]. This may suggest that Trx can have an important role in the regulation of endogenous sulfhydrated proteins, which have important cellular signaling and metabolic functions.

Overall, diverse redox-induced PTMs of GAPDH are temporally and spatially introduced to coordinate its activity, subcellular localization, and function via the interaction with redox readers and the formation of multi-enzyme regulatory complexes. The function of the redox erasers is critical for restoring the reduced form of GAPDH and thus supporting its glycolytic and moonlighting functions.

\section{Human Pathologies Associated with Dysregulated GAPDH Function}

The dysregulation of GAPDH function by oxPTMs has been associated with various human pathologies, including neurodegeneration and metabolic disorders. Such aberrations in GAPDH function include, among others, altered glycolytic activity, involvement in amyloidogenesis and induction of apoptosis. Therefore, GAPDH is an attractive target for the development of diagnostic and therapeutic approaches. This section briefly summarizes the roles GAPDH plays in neurodegeneration and metabolic disorders, as well as therapeutic compounds that target redox-modified GAPDH.

\subsection{GAPDH in Neurodegeneration}

Neurodegenerative diseases are pathological conditions in which the nervous system progressively deteriorates, eventually leading to neuronal death. Aberrant GAPDH function has been associated with different neurodegenerative pathologies, including Alzheimer's disease (AD), Parkinson's disease (PD) and Huntington's disease (HD). It is well known that oxidative stress is linked to the progression of different neurodegenerative pathologies. In vitro studies of GAPDH oxidation were shown to induce structural changes, and intermolecular disulfide bond formation, which cause aggregation of this enzyme $[57,93]$. GAPDH aggregates were observed in post-mortem brain extracts of AD patients $[90,134]$, while aged brains of AD transgenic mice contain insoluble disulfide-bonded form of GAPDH, which does not occur in control mice [90]. Oxidized GAPDH has also been directly linked to $\mathrm{AD}$ progression through its association with amyloidogenic proteins e.g., amyloid- $\beta(A \beta)$ and Tau. The progression of $\mathrm{AD}$ is linked to the accumulation of extracellular $\mathrm{A} \beta$ deposits in the brain, which are induced by oxidative stress and eventually lead to the formation of amyloid plaques and neuronal death. Oxidized GAPDH is capable of forming a complex with soluble $A \beta$ and accelerating its aggregation [135]. On the contrary, the reduced form of GAPDH is unable to form a stable complex with $A \beta$. Studies on the post-mortem AD brain tissues showed that GAPDH co-localizes with both plaque-like structures and neurofibrillary tangles in AD patient brains [134]. Similarly, in PD, GAPDH was found to promote the aggregation of the amyloidogenic protein, $\alpha$-synuclein, into Lewy body-like inclusions [136]. 
Different oxPTMs on GAPDH, e.g., nitrosylation and glutathionylation, have been reported in AD. Studies have reported a 7-fold and 2-fold increase in the level of glutathionylated and nitrosylated GAPDH, respectively, in the brains of AD patients, compared to control individuals $[137,138]$. Both these modifications decrease the glycolytic function of GAPDH, and may contribute to the loss of neuronal function in AD brains. Furthermore, oxPTMs, e.g., nitrosylation, may promote pathological nuclear targeting of GAPDH. Indeed, nuclear GAPDH was observed in postmortem brain tissues of AD [90,139] and PD [140] patients, and HD transgenic mice [141], indicating that nuclear targeting of the enzyme may be a common pathological feature in different neurodegenerative pathologies. Interestingly, the nuclear GAPDH in samples of AD brains $[90,139]$ was found in an aggregated form, suggesting that nuclear translocation and amyloidogenesis of GAPDH may operate synergistically in neurodegeneration. Studies in AD have also shown that the neurotoxic $A \beta$ is capable of inducing disulfide bond formation on GAPDH, which can promote its nuclear translocation and pro-apoptotic function $[90,139]$.

\subsection{GAPDH in Metabolic Disorders}

Dysregulated GAPDH function is also implicated in metabolic disorders, particularly diabetes. Hyperglycemia is a common diabetic condition that causes vascular pathology in tissues throughout the body and associates with superoxide generation [142]. Hyperglycemia-induced superoxide production has been linked to the inhibition of GAPDH glycolytic activity, resulting in the activation of protein kinase $\mathrm{C}$ signaling, hexosamine biosynthetic pathway, and generation of advanced glycation end products (AGEs) [143-146]. Redox-induced PTMs of GAPDH were reported in several studies on diabetic retinopathy, a disease resulting from chronic hyperglycemia. Hyperglycemic conditions were shown to induce nuclear translocation of GAPDH and consequent apoptosis of human retinal Müller and pericyte cells [147-151], both of which undergo cell death in diabetic retinopathy [150]. Importantly, this apoptotic cascade is dependent on GAPDH-Siah-1 complex formation [147,148], which is known to be promoted by GAPDH nitrosylation [8]. These findings are supported by the demonstration that R-(-)-Deprenyl, a drug that prevents S-nitrosylation of GAPDH, can reduce nuclear GAPDH accumulation and associated apoptosis in human Müller cells [149]. Hyperglycemia-induced superoxide and nitric oxide production may also lead to the accumulation of peroxynitrite and protein nitration. Indeed, increased nitration of GAPDH has been detected in the retina of diabetic rats [152].

\subsection{Therapeutic Targeting of Redox-Modified GAPDH}

The development of compounds capable of counteracting the aberrant effects of oxPTMs on GAPDH function in human pathologies has emerged as a promising direction of research. Several compounds have been already developed, including the PD drug R-(-)-Deprenyl and its derivative TCH346, which bind to GAPDH, preventing its $S$-nitrosylation and associated nuclear translocation [153]. Notably, R-(-)-Deprenyl can prevent cell death induced by etoposide, a process associated with nuclear translocation of GAPDH [153]. Similarly, a synthetic compound named AXP3009, binds to the redox-sensitive Cys152 of Plasmodium falciparum GAPDH, and reduces nuclear translocation of GAPDH and associated cellular apoptosis [154,155].

Although R-(-)-Deprenyl is a potent inhibitor of GAPDH nuclear translocation, it is not capable of averting GAPDH aggregation, highlighting the multifactorial nature of redox-induced GAPDH dysregulation in pathologies. In contrast, the naturally occurring compound piceatannol was reported to prevent both nuclear translocation and aggregation of GAPDH [156]. Piceatannol was demonstrated to covalently bind the catalytic cysteine of GAPDH and preclude GAPDH nuclear translocation and apoptosis in cells exposed to oxidative stress, while also preventing formation of intermolecular disulfide bonds and associated GAPDH aggregation [156]. Several small molecule compounds of plant origin have been recently shown to inhibit oxidative stress-induced GAPDH aggregation [157], by binding to the $\mathrm{NAD}^{+}$-binding site of GAPDH. Among these, the compounds RX409 and RX426 were protective against cultured neuroblastoma cell death induced by hydrogen peroxide, as well as 
murine brain injury and associated motor impairments induced by malonic acid injection; in both settings, protection was accompanied by reduced GAPDH aggregation [157].

\section{Conclusions}

Different metabolites produced during cellular stress (metabolic and oxidative stress) contribute to the redox regulation of numerous proteins and signaling pathways, which can direct the cellular machinery toward cell survival or death. By introducing redox modifications on target proteins, these metabolites may alter the conformation, subcellular localization, and function of the target protein, and modulate its downstream interactions with partners and signaling complexes. GAPDH is an example of a well-studied protein, which is redox regulated. Its redox-sensitive catalytic cysteine is considered to be a "hub" of different oxPTMs, which direct GAPDH toward different cellular compartments and numerous non-glycolytic functions. These oxPTMs can enhance or diminish the interaction of GAPDH with various downstream partners (oxGAPDH readers) in different cellular organelles, where it can participate either in cell survival or death. The removal of oxPTMs involves different cellular recycling pathways (redox erasers), which reduce the GAPDH catalytic cysteine and restore its glycolytic function. This highlights the complexity of the redox regulatory mechanisms within cells. The dysregulation of GAPDH during oxidative stress has been associated with human pathologies, including neurodegenerative diseases (AD, PD and HD), and metabolic disorders, among others. Given the association of oxPTMs on GAPDH with different diseases, there are still many unknown mechanisms/interactions of GAPDH that remain to be explored and understood. Future studies on deciphering the role of regulatory interactions and oxPTMs of GAPDH in health and disease will provide the insight and direction needed for advancing the development of novel diagnostic and therapeutic approaches targeting GAPDH.

Author Contributions: M.-A.T. researched the data and wrote the first draft of the manuscript with the exception of Section 5. B.Z. researched the data and wrote the first draft of Section 5. I.G. discussed article content and was involved in editing and revising the manuscript. All authors have read and agreed to the published version of the manuscript.

Funding: This work was funded by grants to I.G. (UCLB 13-014 and 11-018; Rosetrees Trust CM239-F2; BBSRC BB/L010410/1 and BB/S009027/1).

Acknowledgments: We thank Helmut Sies (Heinrich-Heine-Universität, Germany), Elias Arnér (Karolinska Institutet, Sweden) and Jerome Gouge (Birkbeck, London) for critically reading the manuscript. We apologize to those authors whose primary work we did not reference in this review due to space restrictions.

Conflicts of Interest: The authors declare no conflict of interest.

\section{References}

1. Michels, S.; Rogalska, E.; Branlant, G. Phosphate-binding sites in phosphorylating glyceraldehyde-3-phosphate dehydrogenase from Bacillus stearothermophilus. Eur. J. Biochem. 1996, 235, 641-647. [CrossRef] [PubMed]

2. Weber, J.P.; Bernhard, S.A. Transfer of 1,3-diphosphoglycerate between glyceraldehyde-3-phosphate dehydrogenase and 3-phosphoglycerate kinase via an enzyme-substrate-enzyme complex. Biochemistry 1982, 21, 4189-4194. [CrossRef] [PubMed]

3. Singh, R.; Green, M.R. Sequence-specific binding of transfer RNA by glyceraldehyde-3-phosphate dehydrogenase. Science 1993, 259, 365-368. [CrossRef] [PubMed]

4. Tisdale, E.J. Glyceraldehyde-3-phosphate dehydrogenase is required for vesicular transport in the early secretory pathway. J. Biol. Chem. 2001, 276, 2480-2486. [CrossRef]

5. Raje, C.I.; Kumar, S.; Harle, A.; Nanda, J.S.; Raje, M. The macrophage cell surface glyceraldehyde-3-phosphate dehydrogenase is a novel transferrin receptor. J. Biol. Chem. 2007, 282, 3252-3261. [CrossRef]

6. Azam, S.; Jouvet, N.; Jilani, A.; Vongsamphanh, R.; Yang, X.; Yang, S.; Ramotar, D. Human glyceraldehyde-3phosphate dehydrogenase plays a direct role in reactivating oxidized forms of the DNA repair enzyme APE1. J. Biol. Chem. 2008, 283, 30632-30641. [CrossRef] 
7. Demarse, N.A.; Ponnusamy, S.; Spicer, E.K.; Apohan, E.; Baatz, J.E.; Ogretmen, B.; Davies, C. Direct binding of glyceraldehyde 3-phosphate dehydrogenase to telomeric DNA protects telomeres against chemotherapy-induced rapid degradation. J. Mol. Biol. 2009, 394, 789-803. [CrossRef]

8. Hara, M.R.; Agrawal, N.; Kim, S.F.; Cascio, M.B.; Fujimuro, M.; Ozeki, Y.; Takahashi, M.; Cheah, J.H.; Tankou, S.K.; Hester, L.D.; et al. S-nitrosylated GAPDH initiates apoptotic cell death by nuclear translocation following Siah1 binding. Nat. Cell Biol. 2005, 7, 665-674. [CrossRef]

9. Sirover, M.A. On the functional diversity of glyceraldehyde-3-phosphate dehydrogenase: Biochemical mechanisms and regulatory control. Biochim. Biophys. Acta 2011, 1810, 741-751. [CrossRef]

10. Ventura, M.; Mateo, F.; Serratosa, J.; Salaet, I.; Carujo, S.; Bachs, O.; Pujol, M.J. Nuclear translocation of glyceraldehyde-3-phosphate dehydrogenase is regulated by acetylation. Int. J. Biochem. Cell Biol. 2010, 42, 1672-1680. [CrossRef]

11. Baba, T.; Kobayashi, H.; Kawasaki, H.; Mineki, R.; Naito, H.; Ohmori, D. Glyceraldehyde-3-phosphate dehydrogenase interacts with phosphorylated Akt resulting from increased blood glucose in rat cardiac muscle. FEBS Lett 2010, 584, 2796-2800. [CrossRef] [PubMed]

12. Laschet, J.J.; Minier, F.; Kurcewicz, I.; Bureau, M.H.; Trottier, S.; Jeanneteau, F.; Griffon, N.; Samyn, B.; Van Beeumen, J.; Louvel, J.; et al. Glyceraldehyde-3-phosphate dehydrogenase is a GABAA receptor kinase linking glycolysis to neuronal inhibition. J. Neurosci. 2004, 24, 7614-7622. [CrossRef] [PubMed]

13. Park, J.; Han, D.; Kim, K.; Kang, Y.; Kim, Y. O-GlcNAcylation disrupts glyceraldehyde-3-phosphate dehydrogenase homo-tetramer formation and mediates its nuclear translocation. Biochim. Biophys. Acta 2009, 1794, 254-262. [CrossRef] [PubMed]

14. Dimmeler, S.; Brune, B. Characterization of a nitric-oxide-catalysed ADP-ribosylation of glyceraldehyde-3-phosphate dehydrogenase. Eur. J. Biochem. 1992, 210, 305-310. [CrossRef] [PubMed]

15. Molina y Vedia, L.; McDonald, B.; Reep, B.; Brune, B.; Di Silvio, M.; Billiar, T.R.; Lapetina, E.G. Nitric oxide-induced $S$-nitrosylation of glyceraldehyde-3-phosphate dehydrogenase inhibits enzymatic activity and increases endogenous ADP-ribosylation. J. Biol. Chem. 1992, 267, 24929-24932.

16. Cahuana, G.M.; Tejedo, J.R.; Jimenez, J.; Ramirez, R.; Sobrino, F.; Bedoya, F.J. Nitric oxide-induced carbonylation of Bcl-2, GAPDH and ANT precedes apoptotic events in insulin-secreting RINm5F cells. Exp. Cell Res. 2004, 293, 22-30. [CrossRef]

17. Mustafa, A.K.; Gadalla, M.M.; Sen, N.; Kim, S.; Mu, W.; Gazi, S.K.; Barrow, R.K.; Yang, G.; Wang, R.; Snyder, S.H. H2S signals through protein S-sulfhydration. Sci. Signal. 2009, 2, ra72. [CrossRef]

18. Grant, C.M.; Quinn, K.A.; Dawes, I.W. Differential protein S-thiolation of glyceraldehyde-3-phosphate dehydrogenase isoenzymes influences sensitivity to oxidative stress. Mol. Cell Biol. 1999, 19, 2650-2656. [CrossRef]

19. Butera, G.; Mullappilly, N.; Masetto, F.; Palmieri, M.; Scupoli, M.T.; Pacchiana, R.; Donadelli, M. Regulation of autophagy by nuclear GAPDH and Its aggregates in cancer and neurodegenerative disorders. Int. J. Mol. Sci. 2019, 20, 2062. [CrossRef]

20. Tsuchiya, Y.; Zhyvoloup, A.; Bakovic, J.; Thomas, N.; Yu, B.Y.K.; Das, S.; Orengo, C.; Newell, C.; Ward, J.; Saladino, G.; et al. Protein CoAlation and antioxidant function of coenzyme A in prokaryotic cells. Biochem. J. 2018, 475, 1909-1937. [CrossRef]

21. Stincone, A.; Prigione, A.; Cramer, T.; Wamelink, M.M.; Campbell, K.; Cheung, E.; Olin-Sandoval, V.; Gruning, N.M.; Kruger, A.; Tauqeer Alam, M.; et al. The return of metabolism: Biochemistry and physiology of the pentose phosphate pathway. Biol. Rev. Camb. Philos. Soc. 2015, 90, 927-963. [CrossRef] [PubMed]

22. Ralser, M.; Wamelink, M.M.; Kowald, A.; Gerisch, B.; Heeren, G.; Struys, E.A.; Klipp, E.; Jakobs, C.; Breitenbach, M.; Lehrach, H.; et al. Dynamic rerouting of the carbohydrate flux is key to counteracting oxidative stress. J. Biol. 2007, 6, 10. [CrossRef] [PubMed]

23. Peralta, D.; Bronowska, A.K.; Morgan, B.; Doka, E.; Van Laer, K.; Nagy, P.; Grater, F.; Dick, T.P. A proton relay enhances $\mathrm{H}_{2} \mathrm{O}_{2}$ sensitivity of GAPDH to facilitate metabolic adaptation. Nat. Chem. Biol. 2015, 11, 156-163. [CrossRef] [PubMed]

24. Cai, Z.; Yan, L.J. Protein oxidative modifications: Beneficial roles in disease and health. J. Biochem. Pharmacol. Res. 2013, 1, 15-26.

25. Dalle-Donne, I.; Rossi, R.; Colombo, G.; Giustarini, D.; Milzani, A. Protein S-glutathionylation: A regulatory device from bacteria to humans. Trends Biochem. Sci. 2009, 34, 85-96. [CrossRef]

26. Sies, H.; Berndt, C.; Jones, D.P. Oxidative Stress. Annu. Rev. Biochem. 2017, 86, 715-748. [CrossRef] 
27. Sies, H.; Jones, D.P. Reactive oxygen species (ROS) as pleiotropic physiological signalling agents. Nat. Rev. Mol. Cell Biol. 2020, 21, 363-383. [CrossRef]

28. Sies, H. Hydrogen peroxide as a central redox signaling molecule in physiological oxidative stress: Oxidative eustress. Redox Biol. 2017, 11, 613-619. [CrossRef]

29. Paulsen, C.E.; Carroll, K.S. Cysteine-mediated redox signaling: Chemistry, biology, and tools for discovery. Chem. Rev. 2013, 113, 4633-4679. [CrossRef]

30. Bruce King, S. Potential biological chemistry of hydrogen sulfide (H2S) with the nitrogen oxides. Free Radic. Biol. Med. 2013, 55, 1-7. [CrossRef]

31. Gould, N.; Doulias, P.T.; Tenopoulou, M.; Raju, K.; Ischiropoulos, H. Regulation of protein function and signaling by reversible cysteine S-nitrosylation. J. Biol. Chem. 2013, 288, 26473-26479. [CrossRef] [PubMed]

32. Jones, D.P.; Sies, H. The Redox Code. Antioxid. Redox Signal. 2015, 23, 734-746. [CrossRef] [PubMed]

33. Rossmann, M.G.; Moras, D.; Olsen, K.W. Chemical and biological evolution of nucleotide-binding protein. Nature 1974, 250, 194-199. [CrossRef] [PubMed]

34. Olsen, K.W.; Moras, D.; Rossmann, M.G.; Harris, J.I. Sequence variability and structure of D-glyceraldehyde-3-phosphate dehydrogenase. J. Biol. Chem. 1975, 250, 9313-9321.

35. Warizaya, M.; Kinoshita, T.; Kato, A.; Nakajima, H.; Fujii, T. Cloning, expression, purification, crystallization and preliminary X-ray analysis of human liver glyceraldehyde-3-phosphate dehydrogenase. Acta Crystallogr. D Biol. Crystallogr. 2004, 60, 567-568. [CrossRef]

36. Jenkins, J.L.; Tanner, J.J. High-resolution structure of human D-glyceraldehyde-3-phosphate dehydrogenase. Acta Crystallogr. D Biol. Crystallogr. 2006, 62, 290-301. [CrossRef]

37. Sirover, M.A. Structural analysis of glyceraldehyde-3-phosphate dehydrogenase functional diversity. Int. J. Biochem. Cell Biol. 2014, 7, 20-26. [CrossRef]

38. Polgar, L. Ion-pair formation as a source of enhanced reactivity of the essential thiol group of D-glyceraldehyde-3-phosphate dehydrogenase. Eur. J. Biochem. 1975, 51, 63-71. [CrossRef]

39. Corbier, C.; Michels, S.; Wonacott, A.J.; Branlant, G. Characterization of the two anion-recognition sites of glyceraldehyde-3-phosphate dehydrogenase from Bacillus stearothermophilus by site-directed mutagenesis and chemical modification. Biochemistry 1994, 33, 3260-3265. [CrossRef]

40. Hildebrandt, T.; Knuesting, J.; Berndt, C.; Morgan, B.; Scheibe, R. Cytosolic thiol switches regulating basic cellular functions: GAPDH as an information hub? Biol. Chem. 2015, 396, 523-537. [CrossRef]

41. Little, C.; O'Brien, P.J. (Mechanism of peroxide-inactivation of the sulphydryl enzyme glyceraldehyde-3-phosphate dehydrogenase. Eur. J. Biochem. 1969, 10, 533-538. [CrossRef] [PubMed]

42. Hancock, J.T.; Henson, D.; Nyirenda, M.; Desikan, R.; Harrison, J.; Lewis, M.; Hughes, J.; Neill, S.J. Proteomic identification of glyceraldehyde 3-phosphate dehydrogenase as an inhibitory target of hydrogen peroxide in Arabidopsis. Plant. Physiol. Biochem. 2005, 43, 828-835. [CrossRef] [PubMed]

43. Baty, J.W.; Hampton, M.B.; Winterbourn, C.C. Proteomic detection of hydrogen peroxide-sensitive thiol proteins in Jurkat cells. Biochem. J. 2005, 389, 785-795. [CrossRef] [PubMed]

44. Tsuchiya, Y.; Peak-Chew, S.Y.; Newell, C.; Miller-Aidoo, S.; Mangal, S.; Zhyvoloup, A.; Bakovic, J.; Malanchuk, O.; Pereira, G.C.; Kotiadis, V.; et al. Protein CoAlation: A redox-regulated protein modification by coenzyme A in mammalian cells. Biochem. J. 2017, 474, 2489-2508. [CrossRef] [PubMed]

45. Dixon, D.P.; Skipsey, M.; Grundy, N.M.; Edwards, R. Stress-induced protein S-glutathionylation in Arabidopsis. Plant. Physiol. 2005, 138, 2233-2244. [CrossRef] [PubMed]

46. Imber, M.; Huyen, N.T.T.; Pietrzyk-Brzezinska, A.J.; Loi, V.V.; Hillion, M.; Bernhardt, J.; Tharichen, L.; Kolsek, K.; Saleh, M.; Hamilton, C.J.; et al. Protein S-bacillithiolation functions in thiol protection and redox regulation of the glyceraldehyde-3-phosphate dehydrogenase Gap in Staphylococcus aureus under hypochlorite stress. Antioxid. Redox Signal. 2018, 28, 410-430. [CrossRef]

47. Hillion, M.; Imber, M.; Pedre, B.; Bernhardt, J.; Saleh, M.; Loi, V.V.; Maass, S.; Becher, D.; Astolfi Rosado, L.; Adrian, L.; et al. The glyceraldehyde-3-phosphate dehydrogenase GapDH of Corynebacterium diphtheriae is redox-controlled by protein S-mycothiolation under oxidative stress. Sci. Rep. 2017, 7, 5020. [CrossRef]

48. Shenton, D.; Grant, C.M. Protein S-thiolation targets glycolysis and protein synthesis in response to oxidative stress in the yeast Saccharomyces cerevisiae. Biochem. J. 2003, 374, 513-519. [CrossRef]

49. Akter, S.; Huang, J.; Bodra, N.; De Smet, B.; Wahni, K.; Rombaut, D.; Pauwels, J.; Gevaert, K.; Carroll, K.; Van Breusegem, F.; et al. DYn-2 Based Identification of Arabidopsis Sulfenomes. Mol. Cell Proteom. 2015, 14, 1183-1200. [CrossRef] 
50. Yang, J.; Gupta, V.; Carroll, K.S.; Liebler, D.C. Site-specific mapping and quantification of protein S-sulphenylation in cells. Nat. Commun. 2014, 5, 4776. [CrossRef]

51. Huang, J.; Willems, P.; Van Breusegem, F.; Messens, J. Pathways crossing mammalian and plant sulfenomic landscapes. Free Radic. Biol. Med. 2018, 122, 193-201. [CrossRef] [PubMed]

52. Gupta, V.; Yang, J.; Liebler, D.C.; Carroll, K.S. Diverse redoxome reactivity profiles of carbon nucleophiles. J. Am. Chem. Soc. 2017, 39, 5588-5595. [CrossRef] [PubMed]

53. Waszczak, C.; Akter, S.; Eeckhout, D.; Persiau, G.; Wahni, K.; Bodra, N.; Van Molle, I.; De Smet, B.; Vertommen, D.; Gevaert, K.; et al. Sulfenome mining in Arabidopsis thaliana. Proc. Natl. Acad. Sci. USA 2014, 111, 11545-11550. [CrossRef] [PubMed]

54. Benitez, L.V.; Allison, W.S. The inactivation of the acyl phosphatase activity catalyzed by the sulfenic acid form of glyceraldehyde 3-phosphate dehydrogenase by dimedone and olefins. J. Biol. Chem. 1974, 249, 6234-6243.

55. Zaffagnini, M.; Fermani, S.; Calvaresi, M.; Orru, R.; Iommarini, L.; Sparla, F.; Falini, G.; Bottoni, A.; Trost, P. Tuning cysteine reactivity and sulfenic acid stability by protein microenvironment in glyceraldehyde-3-phosphate dehydrogenases of Arabidopsis thaliana. Antioxid. Redox Signal. 2016, 24, 502-517. [CrossRef]

56. Cseke, E.; Boross, L. Factors affecting the reactivity of the activated SH-group of D-glyceraldehyde 3-phosphate dehydrogenase. Acta Biochim. Biophys. Acad. Sci. Hung. 1970, 5, 385-397.

57. Nakajima, H.; Amano, W.; Fujita, A.; Fukuhara, A.; Azuma, Y.T.; Hata, F.; Inui, T.; Takeuchi, T. The active site cysteine of the proapoptotic protein glyceraldehyde-3-phosphate dehydrogenase is essential in oxidative stress-induced aggregation and cell death. J. Biol. Chem. 2007, 282, 26562-26574. [CrossRef]

58. Barinova, K.V.; Serebryakova, M.V.; Muronetz, V.I.; Schmalhausen, E.V. S-glutathionylation of glyceraldehyde-3-phosphate dehydrogenase induces formation of C150-C154 intrasubunit disulfide bond in the active site of the enzyme. Biochim. Biophys. Acta Gen. Subj. 2007, 1861, 3167-3177. [CrossRef]

59. Bedhomme, M.; Adamo, M.; Marchand, C.H.; Couturier, J.; Rouhier, N.; Lemaire, S.D.; Zaffagnini, M.; Trost, P. Glutathionylation of cytosolic glyceraldehyde-3-phosphate dehydrogenase from the model plant Arabidopsis thaliana is reversed by both glutaredoxins and thioredoxins in vitro. Biochem. J. 2012, 445, 337-347. [CrossRef]

60. Van Laer, K.; Hamilton, C.J.; Messens, J. Low-molecular-weight thiols in thiol-disulfide exchange. Antioxid. Redox Signal. 2013, 18, 1642-1653. [CrossRef]

61. Loi, V.V.; Rossius, M.; Antelmann, H. Redox regulation by reversible protein S-thiolation in bacteria. Front. Microbiol. 2015, 6, 187. [CrossRef] [PubMed]

62. Tsuji, K.; Yoon, K.S.; Ogo, S. Glyceraldehyde-3-phosphate dehydrogenase from Citrobacter sp. S-77 is post-translationally modified by CoA (protein CoAlation) under oxidative stress. FEBS Open Bio 2019, 9, 53-73. [CrossRef] [PubMed]

63. Lillig, C.H.; Berndt, C. Cellular functions of glutathione. Biochim. Biophys. Acta 2013, 1830, 3137-3138. [CrossRef] [PubMed]

64. Brandes, N.; Schmitt, S.; Jakob, U. Thiol-based redox switches in eukaryotic proteins. Antioxid. Redox Signal. 2009, 11, 997-1014. [CrossRef]

65. Pan, S.; Berk, B.C. Glutathiolation regulates tumor necrosis factor-alpha-induced caspase-3 cleavage and apoptosis: Key role for glutaredoxin in the death pathway. Circ. Res. 2007, 100, 213-219. [CrossRef]

66. Cross, J.V.; Templeton, D.J. Oxidative stress inhibits MEKK1 by site-specific glutathionylation in the ATP-binding domain. Biochem. J. 2004, 381, 675-683. [CrossRef]

67. Haendeler, J. Thioredoxin-1 and posttranslational modifications. Antioxid. Redox Signal. 2006, 8, $1723-1728$. [CrossRef]

68. Huang, Z.; Pinto, J.T.; Deng, H.; Richie, J.P., Jr. Inhibition of caspase-3 activity and activation by protein glutathionylation. Biochem. Pharmacol. 2008, 75, 2234-2244. [CrossRef]

69. Greetham, D.; Vickerstaff, J.; Shenton, D.; Perrone, G.G.; Dawes, I.W.; Grant, C.M. Thioredoxins function as deglutathionylase enzymes in the yeast Saccharomyces cerevisiae. BMC Biochem. 2010, 11, 3. [CrossRef]

70. Kehr, S.; Jortzik, E.; Delahunty, C.; Yates, J.R., 3rd; Rahlfs, S.; Becker, K. Protein S-glutathionylation in malaria parasites. Antioxid. Redox Signal. 2011, 15, 2855-2865. [CrossRef]

71. Mohr, S.; Hallak, H.; de Boitte, A.; Lapetina, E.G.; Brune, B. Nitric oxide-induced S-glutathionylation and inactivation of glyceraldehyde-3-phosphate dehydrogenase. J. Biol. Chem. 1999, 274, 9427-9430. [CrossRef] [PubMed] 
72. Zaffagnini, M.; Morisse, S.; Bedhomme, M.; Marchand, C.H.; Festa, M.; Rouhier, N.; Lemaire, S.D.; Trost, P. Mechanisms of nitrosylation and denitrosylation of cytoplasmic glyceraldehyde-3-phosphate dehydrogenase from Arabidopsis thaliana. J. Biol. Chem. 2013, 288, 22777-22789. [CrossRef] [PubMed]

73. Giustarini, D.; Milzani, A.; Aldini, G.; Carini, M.; Rossi, R.; Dalle-Donne, I. S-nitrosation versus S-glutathionylation of protein sulfhydryl groups by S-nitrosoglutathione. Antioxid. Redox Signal. 2005, 7, 930-939. [CrossRef] [PubMed]

74. Liu, L.; Hausladen, A.; Zeng, M.; Que, L.; Heitman, J.; Stamler, J.S. A metabolic enzyme for S-nitrosothiol conserved from bacteria to humans. Nature 2010, 410, 490-494. [CrossRef] [PubMed]

75. Jothivasan, V.K.; Hamilton, C.J. Mycothiol: Synthesis, biosynthesis and biological functions of the major low molecular weight thiol in actinomycetes. Nat. Prod. Rep. 2008, 25, 1091-1117. [CrossRef] [PubMed]

76. Newton, G.L.; Buchmeier, N.; Fahey, R.C. Biosynthesis and functions of mycothiol, the unique protective thiol of Actinobacteria. Microbiol. Mol. Biol. Rev. 2008, 72, 471-494. [CrossRef] [PubMed]

77. Spies, H.S.; Steenkamp, D.J. Thiols of intracellular pathogens. Identification of ovothiol A in Leishmania donovani and structural analysis of a novel thiol from Mycobacterium bovis. Eur. J. Biochem. 1994, 224, $203-213$. [CrossRef]

78. Sakuda, S.; Zhou, Z.Y.; Yamada, Y. Structure of a novel disulfide of 2-(N-acetylcysteinyl)amido-2deoxy-alpha-D-glucopyranosyl-myo-inositol produced by Streptomyces sp. Biosci. Biotechnol. Biochem. 1994, 58, 1347-1348. [CrossRef]

79. Newton, G.L.; Rawat, M.; La Clair, J.J.; Jothivasan, V.K.; Budiarto, T.; Hamilton, C.J.; Claiborne, A.; Helmann, J.D.; Fahey, R.C. Bacillithiol is an antioxidant thiol produced in Bacilli. Nat. Chem. Biol. 2009, 5, 625-627. [CrossRef]

80. Gout, I. Coenzyme A: A protective thiol in bacterial antioxidant defence. Biochem. Soc. Trans. 2019, 47, 469-476. [CrossRef]

81. Delcardayre, S.B.; Davies, J.E. Staphylococcus aureus coenzyme A disulfide reductase, a new subfamily of pyridine nucleotide-disulfide oxidoreductase. Sequence, expression, and analysis of cdr. J. Biol. Chem. 1998, 273, 5752-5757. [CrossRef] [PubMed]

82. Leonardi, R.; Zhang, Y.M.; Rock, C.O.; Jackowski, S. Coenzyme A: Back in action. Prog. Lipid Res. 2005, 44, 125-153. [CrossRef] [PubMed]

83. Malanchuk, O.M.; Panasyuk, G.G.; Serbin, N.M.; Gout, I.T.; Filonenko, V.V. Generation and characterization of monoclonal antibodies specific to coenzyme A. Biopolym. Cell 2015, 31, 187-192. [CrossRef]

84. Anand, P.; Hausladen, A.; Wang, Y.J.; Zhang, G.F.; Stomberski, C.; Brunengraber, H.; Hess, D.T.; Stamler, J.S. Identification of S-nitroso-CoA reductases that regulate protein S-nitrosylation. Proc. Natl. Acad. Sci. USA 2014, 111, 18572-18577. [CrossRef]

85. Hess, D.T.; Matsumoto, A.; Kim, S.O.; Marshall, H.E.; Stamler, J.S. Protein S-nitrosylation: Purview and parameters. Nat. Rev. Mol. Cell Biol. 2005, 6, 150-166. [CrossRef]

86. Hogg, N. The biochemistry and physiology of S-nitrosothiols. Annu. Rev. Pharmacol. Toxicol. 2002, 42, 585-600. [CrossRef]

87. Zhang, D.; Macinkovic, I.; Devarie-Baez, N.O.; Pan, J.; Park, C.M.; Carroll, K.S.; Filipovic, M.R.; Xian, M. Detection of protein $S$-sulfhydration by a tag-switch technique. Angew. Chem. Int. Ed. Engl. 2014, 53, 575-581. [CrossRef]

88. Jarosz, A.P.; Wei, W.; Gauld, J.W.; Auld, J.; Ozcan, F.; Aslan, M.; Mutus, B. Glyceraldehyde 3-phosphate dehydrogenase (GAPDH) is inactivated by $S$-sulfuration in vitro. Free Radic. Biol. Med. 2015, 89, 512-521. [CrossRef]

89. Gao, X.H.; Krokowski, D.; Guan, B.J.; Bederman, I.; Majumder, M.; Parisien, M.; Diatchenko, L.; Kabil, O.; Willard, B.; Banerjee, R.; et al. Quantitative H2S-mediated protein sulfhydration reveals metabolic reprogramming during the integrated stress response. Elife 2015, 4, e10067. [CrossRef]

90. Cumming, R.C.; Schubert, D. Amyloid-beta induces disulfide bonding and aggregation of GAPDH in Alzheimer's disease. FASEB J. 2005, 19, 2060-2062. [CrossRef]

91. Samson, A.L.; Knaupp, A.S.; Sashindranath, M.; Borg, R.J.; Au, A.E.; Cops, E.J.; Saunders, H.M.; Cody, S.H.; McLean, C.A.; Nowell, C.J.; et al. Nucleocytoplasmic coagulation: An injury-induced aggregation event that disulfide crosslinks proteins and facilitates their removal by plasmin. Cell Rep. 2012, 2, 889-901. [CrossRef] [PubMed] 
92. Nakajima, H.; Amano, W.; Fukuhara, A.; Kubo, T.; Misaki, S.; Azuma, Y.T.; Inui, T.; Takeuchi, T. An aggregate-prone mutant of human glyceraldehyde-3-phosphate dehydrogenase augments oxidative stress-induced cell death in SH-SY5Y cells. Biochem. Biophys. Res. Commun. 2009, 390, 1066-1071. [CrossRef] [PubMed]

93. Samson, A.L.; Knaupp, A.S.; Kass, I.; Kleifeld, O.; Marijanovic, E.M.; Hughes, V.A.; Lupton, C.J.; Buckle, A.M.; Bottomley, S.P.; Medcalf, R.L. Oxidation of an exposed methionine instigates the aggregation of glyceraldehyde-3-phosphate dehydrogenase. J. Biol. Chem. 2014, 289, 26922-26936. [CrossRef] [PubMed]

94. Zaffagnini, M.; Michelet, L.; Massot, V.; Trost, P.; Lemaire, S.D. Biochemical characterization of glutaredoxins from Chlamydomonas reinhardtii reveals the unique properties of a chloroplastic CGFS-type glutaredoxin. J. Biol. Chem. 2008, 283, 8868-8876. [CrossRef]

95. Zaffagnini, M.; Michelet, L.; Marchand, C.; Sparla, F.; Decottignies, P.; Le Marechal, P.; Miginiac-Maslow, M.; Noctor, G.; Trost, P.; Lemaire, S.D. The thioredoxin-independent isoform of chloroplastic glyceraldehyde-3-phosphate dehydrogenase is selectively regulated by glutathionylation. FEBS J. 2007, 274, 212-226. [CrossRef]

96. Wu, C.; Parrott, A.M.; Liu, T.; Jain, M.R.; Yang, Y.; Sadoshima, J.; Li, H. Distinction of thioredoxin transnitrosylation and denitrosylation target proteins by the ICAT quantitative approach. J. Proteom. 2011, 74, 2498-2509. [CrossRef]

97. Wu, C.; Liu, T.; Chen, W.; Oka, S.; Fu, C.; Jain, M.R.; Parrott, A.M.; Baykal, A.T.; Sadoshima, J.; Li, H. Redox regulatory mechanism of transnitrosylation by thioredoxin. Mol. Cell Proteom. 2010, 9, 2262-2275. [CrossRef]

98. Morigasaki, S.; Shimada, K.; Ikner, A.; Yanagida, M.; Shiozaki, K. Glycolytic enzyme GAPDH promotes peroxide stress signaling through multistep phosphorelay to a MAPK cascade. Mol. Cell 2008, 30, 108-113. [CrossRef]

99. Nguyen, A.N.; Lee, A.; Place, W.; Shiozaki, K. Multistep phosphorelay proteins transmit oxidative stress signals to the fission yeast stress-activated protein kinase. Mol. Biol. Cell 2000, 11, 1169-1181. [CrossRef]

100. Aoyama, K.; Mitsubayashi, Y.; Aiba, H.; Mizuno, T. Spy1, a histidine-containing phosphotransfer signaling protein, regulates the fission yeast cell cycle through the Mcs4 response regulator. J. Bacteriol. 2000, 182, 4868-4874. [CrossRef]

101. Kim, J.H.; Lee, S.; Park, J.B.; Lee, S.D.; Kim, J.H.; Ha, S.H.; Hasumi, K.; Endo, A.; Suh, P.G.; Ryu, S.H. Hydrogen peroxide induces association between glyceraldehyde 3-phosphate dehydrogenase and phospholipase D2 to facilitate phospholipase D2 activation in PC12 cells. J. Neurochem. 2003, 85, 1228-1236. [CrossRef] [PubMed]

102. Lee, S.D.; Lee, B.D.; Han, J.M.; Kim, J.H.; Kim, Y.; Suh, P.G.; Ryu, S.H. Phospholipase D2 activity suppresses hydrogen peroxide-induced apoptosis in PC12 cells. J. Neurochem. 2000, 75, 1053-1059. [CrossRef] [PubMed]

103. Exton, J.H. Phospholipase D. Ann. N. Y. Acad. Sci. 2000, 905, 61-68. [CrossRef] [PubMed]

104. Sen, N.; Hara, M.R.; Ahmad, A.S.; Cascio, M.B.; Kamiya, A.; Ehmsen, J.T.; Agrawal, N.; Hester, L.; Dore, S.; Snyder, S.H.; et al. GOSPEL: A neuroprotective protein that binds to GAPDH upon S-nitrosylation. Neuron 2009, 63, 81-91. [CrossRef] [PubMed]

105. Sen, N.; Hara, M.R.; Kornberg, M.D.; Cascio, M.B.; Bae, B.I.; Shahani, N.; Thomas, B.; Dawson, T.M.; Dawson, V.L.; Snyder, S.H.; et al. Nitric oxide-induced nuclear GAPDH activates p300/CBP and mediates apoptosis. Nat. Cell Biol. 2008, 10, 866-873. [CrossRef] [PubMed]

106. Nakano, K.; Vousden, K.H. PUMA, a novel proapoptotic gene, is induced by p53. Mol. Cell 2001, 7, 683-694. [CrossRef]

107. Kornberg, M.D.; Sen, N.; Hara, M.R.; Juluri, K.R.; Nguyen, J.V.; Snowman, A.M.; Law, L.; Hester, L.D.; Snyder, S.H. GAPDH mediates nitrosylation of nuclear proteins. Nat. Cell Biol. 2010, 12, 1094-1100. [CrossRef]

108. Tristan, C.A.; Ramos, A.; Shahani, N.; Emiliani, F.E.; Nakajima, H.; Noeh, C.C.; Kato, Y.; Takeuchi, T.; Noguchi, T.; Kadowaki, H.; et al. Role of apoptosis signal-regulating kinase 1 (ASK1) as an activator of the GAPDH-Siah1 stress-signaling cascade. J. Biol. Chem. 2015, 290, 56-64. [CrossRef]

109. Yu, Y.; Richardson, D.R. Cellular iron depletion stimulates the JNK and p38 MAPK signaling transduction pathways, dissociation of ASK1-thioredoxin, and activation of ASK1. J. Biol. Chem. 2011, 286, 15413-15427. [CrossRef]

110. Cho, K.J.; Lee, B.I.; Cheon, S.Y.; Kim, H.W.; Kim, H.J.; Kim, G.W. Inhibition of apoptosis signal-regulating kinase 1 reduces endoplasmic reticulum stress and nuclear huntingtin fragments in a mouse model of Huntington disease. Neuroscience 2009, 163, 1128-1134. [CrossRef] 
111. Tarze, A.; Deniaud, A.; Le Bras, M.; Maillier, E.; Molle, D.; Larochette, N.; Zamzami, N.; Jan, G.; Kroemer, G.; Brenner, C. GAPDH, a novel regulator of the pro-apoptotic mitochondrial membrane permeabilization. Oncogene 2007, 26, 2606-2620. [CrossRef] [PubMed]

112. Kohr, M.J.; Murphy, E.; Steenbergen, C. Glyceraldehyde-3-phosphate dehydrogenase acts as a mitochondrial trans-S-nitrosylase in the heart. PLoS ONE 2014, 9, e111448. [CrossRef] [PubMed]

113. Sun, J.; Morgan, M.; Shen, R.F.; Steenbergen, C.; Murphy, E. Preconditioning results in S-nitrosylation of proteins involved in regulation of mitochondrial energetics and calcium transport. Circ. Res. 2007, 101, 1155-1163. [CrossRef] [PubMed]

114. Mir, S.; Sen, T.; Sen, N. Cytokine-induced GAPDH sulfhydration affects PSD95 degradation and memory. Mol. Cell 2014, 56, 786-795. [CrossRef]

115. El-Husseini, A.E.; Schnell, E.; Chetkovich, D.M.; Nicoll, R.A.; Bredt, D.S. PSD-95 involvement in maturation of excitatory synapses. Science 2000, 290, 1364-1368.

116. Arner, E.S.; Holmgren, A. Physiological functions of thioredoxin and thioredoxin reductase. Eur. J. Biochem. 2000, 267, 6102-6109. [CrossRef]

117. Nordberg, J.; Arner, E.S. Reactive oxygen species, antioxidants, and the mammalian thioredoxin system. Free Radic. Biol. Med. 2001, 31, 1287-1312. [CrossRef]

118. Collet, J.F.; Messens, J. Structure, function, and mechanism of thioredoxin proteins. Antioxid. Redox Signal. 2010, 13, 1205-1216. [CrossRef]

119. Williams, C.H., Jr. Mechanism and structure of thioredoxin reductase from Escherichia coli. FASEB J. 1995, 9 , 1267-1276. [CrossRef]

120. Deponte, M. Glutathione catalysis and the reaction mechanisms of glutathione-dependent enzymes. Biochim. Biophys. Acta 2013, 1830, 3217-3266. [CrossRef]

121. Deponte, M.; Lillig, C.H. Enzymatic control of cysteinyl thiol switches in proteins. Biol. Chem. 2015, 396, 401-413. [CrossRef] [PubMed]

122. Chi, B.K.; Gronau, K.; Mader, U.; Hessling, B.; Becher, D.; Antelmann, H. S-bacillithiolation protects against hypochlorite stress in Bacillus subtilis as revealed by transcriptomics and redox proteomics. Mol. Cell Proteom. 2011, 10, M111009506. [CrossRef] [PubMed]

123. Landino, L.M.; Hagedorn, T.D.; Kennett, K.L. Evidence for thiol/disulfide exchange reactions between tubulin and glyceraldehyde-3-phosphate dehydrogenase. Cytoskeleton (Hoboken) 2014, 71, 707-718. [CrossRef] [PubMed]

124. Hwang, N.R.; Yim, S.H.; Kim, Y.M.; Jeong, J.; Song, E.J.; Lee, Y.; Lee, J.H.; Choi, S.; Lee, K.J. Oxidative modifications of glyceraldehyde-3-phosphate dehydrogenase play a key role in its multiple cellular functions. Biochem. J. 2009, 423, 253-264. [CrossRef]

125. Anderson, P.J. The structure and amount of tubulin in cells and tissues. J. Biol. Chem. 1979, 254, $2168-2171$.

126. Landino, L.M.; Robinson, S.H.; Skreslet, T.E.; Cabral, D.M. Redox modulation of tau and microtubule-associated protein-2 by the glutathione/glutaredoxin reductase system. Biochem. Biophys. Res. Commun. 2004, 323, 112-117. [CrossRef]

127. Landino, L.M.; Skreslet, T.E.; Alston, J.A. Cysteine oxidation of tau and microtubule-associated protein-2 by peroxynitrite: Modulation of microtubule assembly kinetics by the thioredoxin reductase system. J. Biol. Chem. 2004, 279, 35101-35105. [CrossRef]

128. Landino, L.M.; Iwig, J.S.; Kennett, K.L.; Moynihan, K.L. Repair of peroxynitrite damage to tubulin by the thioredoxin reductase system. Free Radic. Biol. Med. 2004, 36, 497-506. [CrossRef]

129. Gallogly, M.M.; Mieyal, J.J. Mechanisms of reversible protein glutathionylation in redox signaling and oxidative stress. Curr. Opin. Pharmacol. 2007, 7, 381-391. [CrossRef]

130. Shenton, D.; Perrone, G.; Quinn, K.A.; Dawes, I.W.; Grant, C.M. Regulation of protein S-thiolation by glutaredoxin 5 in the yeast Saccharomyces cerevisiae. J. Biol. Chem. 2002, 277, 16853-16859. [CrossRef]

131. Linzner, N.; Loi, V.V.; Fritsch, V.N.; Tung, Q.N.; Stenzel, S.; Wirtz, M.; Hell, R.; Hamilton, C.J.; Tedin, K.; Fulde, M.; et al. Staphylococcus aureus uses the bacilliredoxin (BrxAB)/bacillithiol disulfide reductase (YpdA) redox pathway to defend against oxidative stress under infections. Front. Microbiol. 2019, 10, 1355. [CrossRef] [PubMed]

132. Li, H.; Wan, A.; Xu, G.; Ye, D. Small changes huge impact: The role of thioredoxin 1 in the regulation of apoptosis by S-nitrosylation. Acta Biochim. Biophys. Sin. 2013, 45, 153-161. [CrossRef] [PubMed] 
133. Ju, Y.; Wu, L.; Yang, G. Thioredoxin 1 regulation of protein S-desulfhydration. Biochem. Biophys. Rep. 2016, 5, 27-34. [CrossRef] [PubMed]

134. Wang, Q.; Woltjer, R.L.; Cimino, P.J.; Pan, C.; Montine, K.S.; Zhang, J.; Montine, T.J. Proteomic analysis of neurofibrillary tangles in Alzheimer disease identifies GAPDH as a detergent-insoluble paired helical filament tau binding protein. FASEB J. 2005, 19, 869-871. [CrossRef] [PubMed]

135. Itakura, M.; Nakajima, H.; Kubo, T.; Semi, Y.; Kume, S.; Higashida, S.; Kaneshige, A.; Kuwamura, M.; Harada, N.; Kita, A.; et al. Glyceraldehyde-3-phosphate Dehydrogenase Aggregates Accelerate Amyloid-beta Amyloidogenesis in Alzheimer Disease. J. Biol. Chem. 2015, 290, 26072-26087. [CrossRef] [PubMed]

136. Tsuchiya, K.; Tajima, H.; Kuwae, T.; Takeshima, T.; Nakano, T.; Tanaka, M.; Sunaga, K.; Fukuhara, Y.; Nakashima, K.; Ohama, E.; et al. Pro-apoptotic protein glyceraldehyde-3-phosphate dehydrogenase promotes the formation of Lewy body-like inclusions. Eur. J. Neurosci. 2005, 21, 317-326. [CrossRef]

137. Newman, S.F.; Sultana, R.; Perluigi, M.; Coccia, R.; Cai, J.; Pierce, W.M.; Klein, J.B.; Turner, D.M.; Butterfield, D.A. An increase in S-glutathionylated proteins in the Alzheimer's disease inferior parietal lobule, a proteomics approach. J. Neurosci. Res. 2007, 85, 1506-1514. [CrossRef]

138. Sultana, R.; Poon, H.F.; Cai, J.; Pierce, W.M.; Merchant, M.; Klein, J.B.; Markesbery, W.R.; Butterfield, D.A. Identification of nitrated proteins in Alzheimer's disease brain using a redox proteomics approach. Neurobiol. Dis. 2006, 22, 76-87. [CrossRef]

139. Tsuchiya, K.; Tajima, H.; Yamada, M.; Takahashi, H.; Kuwae, T.; Sunaga, K.; Katsube, N.; Ishitani, R. Disclosure of a pro-apoptotic glyceraldehyde-3-phosphate dehydrogenase promoter: Anti-dementia drugs depress its activation in apoptosis. Life Sci. 2004, 74, 3245-3258. [CrossRef]

140. Tatton, N.A. Increased caspase 3 and Bax immunoreactivity accompany nuclear GAPDH translocation and neuronal apoptosis in Parkinson's disease. Exp. Neurol. 2000, 166, 29-43. [CrossRef]

141. Senatorov, V.V.; Charles, V.; Reddy, P.H.; Tagle, D.A.; Chuang, D.M. Overexpression and nuclear accumulation of glyceraldehyde-3-phosphate dehydrogenase in a transgenic mouse model of Huntington's disease. Mol. Cell Neurosci. 2003, 22, 285-297. [CrossRef]

142. Stehouwer, C.D.A. Microvascular dysfunction and hyperglycemia: A vicious cycle with widespread consequences. Diabetes 2018, 67, 1729-1741. [CrossRef] [PubMed]

143. Kolm-Litty, V.; Sauer, U.; Nerlich, A.; Lehmann, R.; Schleicher, E.D. High glucose-induced transforming growth factor beta1 production is mediated by the hexosamine pathway in porcine glomerular mesangial cells. J. Clin. Investig. 1998, 101, 160-169. [CrossRef]

144. Koya, D.; King, G.L. Protein kinase C activation and the development of diabetic complications. Diabetes 1998, 47, 859-866. [CrossRef] [PubMed]

145. Du, X.; Matsumura, T.; Edelstein, D.; Rossetti, L.; Zsengeller, Z.; Szabo, C.; Brownlee, M. Inhibition of GAPDH activity by poly(ADP-ribose) polymerase activates three major pathways of hyperglycemic damage in endothelial cells. J. Clin. Investig. 2003, 112, 1049-1057. [CrossRef] [PubMed]

146. Du, X.L.; Edelstein, D.; Rossetti, L.; Fantus, I.G.; Goldberg, H.; Ziyadeh, F.; Wu, J.; Brownlee, M. Hyperglycemia-induced mitochondrial superoxide overproduction activates the hexosamine pathway and induces plasminogen activator inhibitor-1 expression by increasing Sp1 glycosylation. Proc. Natl. Acad. Sci. USA 2000, 7, 12222-12226. [CrossRef] [PubMed]

147. Yego, E.C.; Mohr, S. siah-1 protein is necessary for high glucose-induced glyceraldehyde-3-phosphate dehydrogenase nuclear accumulation and cell death in Muller cells. J. Biol. Chem. 2010, 285, 3181-3190. [CrossRef]

148. Suarez, S.; McCollum, G.W.; Jayagopal, A.; Penn, J.S. High glucose-induced retinal pericyte apoptosis depends on association of GAPDH and Siah1. J. Biol. Chem. 2015, 290, 28311-28320. [CrossRef]

149. Kusner, L.L.; Sarthy, V.P.; Mohr, S. Nuclear translocation of glyceraldehyde-3-phosphate dehydrogenase: A role in high glucose-induced apoptosis in retinal Muller cells. Investig. Ophthalmol. Vis. Sci. 2004, 45, 1553-1561.

150. Feenstra, D.J.; Yego, E.C.; Mohr, S. Modes of retinal cell death in diabetic retinopathy. J. Clin. Exp. Ophthalmol. 2013, 4, 298.

151. Yego, E.C.; Vincent, J.A.; Sarthy, V.; Busik, J.V.; Mohr, S. Differential regulation of high glucose-induced glyceraldehyde-3-phosphate dehydrogenase nuclear accumulation in Muller cells by IL-1beta and IL-6. Investig. Ophthalmol. Vis. Sci. 2009, 50, 1920-1928. [CrossRef] [PubMed] 
152. Kanwar, M.; Kowluru, R.A. Role of glyceraldehyde 3-phosphate dehydrogenase in the development and progression of diabetic retinopathy. Diabetes 2009, 58, 227-234. [CrossRef] [PubMed]

153. Hara, M.R.; Thomas, B.; Cascio, M.B.; Bae, B.I.; Hester, L.D.; Dawson, V.L.; Dawson, T.M.; Sawa, A.; Snyder, S.H. Neuroprotection by pharmacologic blockade of the GAPDH death cascade. Proc. Natl. Acad. Sci. USA 2006, 103, 3887-3889. [CrossRef] [PubMed]

154. Bruno, S.; Pinto, A.; Paredi, G.; Tamborini, L.; De Micheli, C.; La Pietra, V.; Marinelli, L.; Novellino, E.; Conti, P.; Mozzarelli, A. Discovery of covalent inhibitors of glyceraldehyde-3-phosphate dehydrogenase, a target for the treatment of malaria. J. Med. Chem. 2014, 57, 7465-7471. [CrossRef]

155. Dando, I.; Pacchiana, R.; Pozza, E.D.; Cataldo, I.; Bruno, S.; Conti, P.; Cordani, M.; Grimaldi, A.; Butera, G.; Caraglia, M.; et al. UCP2 inhibition induces ROS/Akt/mTOR axis: Role of GAPDH nuclear translocation in genipin/everolimus anticancer synergism. Free Radic. Biol. Med. 2017, 113, 176-189. [CrossRef]

156. Gerszon, J.; Serafin, E.; Buczkowski, A.; Michlewska, S.; Bielnicki, J.A.; Rodacka, A. Functional consequences of piceatannol binding to glyceraldehyde-3-phosphate dehydrogenase. PLoS ONE 2018, 13, e0190656. [CrossRef]

157. Lazarev, V.F.; Nikotina, A.D.; Semenyuk, P.I.; Evstafyeva, D.B.; Mikhaylova, E.R.; Muronetz, V.I.; Shevtsov, M.A.; Tolkacheva, A.V.; Dobrodumov, A.V.; Shavarda, A.L.; et al. Small molecules preventing GAPDH aggregation are therapeutically applicable in cell and rat models of oxidative stress. Free Radic. Biol. Med. 2016, 92, 29-38. [CrossRef]

Publisher's Note: MDPI stays neutral with regard to jurisdictional claims in published maps and institutional affiliations. 